\title{
Strategies Used to by Mothers with Breast Cancer to Apply the Mothering Role: A Qualitative Study
}

\author{
Vahid Zamanzadeh', Akram Ghahramanian², Leila Valizadeh ${ }^{3}$, Effat Mazaheri $^{4 *}$ iD
}

1. Professor in Nursing, Department of Medical Surgical Nursing, Faculty of Nursing and Midwifery, Tabriz University of Medical Sciences, Tabriz, Iran

2. Associate Professor, Department of Medical Surgical Nursing, Faculty of Nursing and Midwifery, Hematology and Oncology Research Center, Tabriz University of Medical Sciences, Tabriz, Iran

3. Professor in Nursing, Department of Pediatric Nursing, Faculty of Nursing and Midwifery, Tabriz University of Medical Sciences, Tabriz, Iran

4. Assistant Professor, Faculty of Nursing and Midwifery, Ardabil University of Medical Sciences, Ardabil, Iran

\begin{tabular}{ll}
\hline \multicolumn{1}{c}{ Article Info } & ABSTRACT \\
\cline { 1 - 2 } $\begin{array}{l}\text { Received: } 2020 / 10 / 03 ; \\
\text { Accepted: } 2021 / 04 / 15 ;\end{array}$ & $\begin{array}{l}\text { Introduction: Women with breast cancer often experience alterations in their mothering } \\
\text { roles both because of the disease and the reduced ability for child care. However, many women } \\
\text { with breast cancer try to play their mothering roles as they did before the disease. This study } \\
\text { aimed to discover the strategies used by Iranian women with breast cancer to manage their } \\
\text { mothering roles in the process of the disease and survival. }\end{array}$
\end{tabular}

10.30699/ajnmc.29.3.220

Original Article

Use your device to scan and read the article online

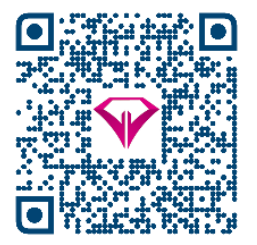

Methods: A qualitative content analysis study was conducted on 23 mothers with breast cancer. Semi-structured interviews were used to collect data and a conventional content analysis method was used to analyze the data simultaneously with data collection.

Results: Totally 1200 non-duplicate codes were extracted from the data and were categorized into four categories. Self-preparation was the first category and included three subcategories, namely, self-awareness for regaining the role, psychological mobilization to continue the role, and seeking informational support. Role reorganizing was the second category and had two subcategories, namely assigning to alternate people, and modifications of maternal duties. Self- and family-reconstruction was the third category and included three subcategories of energy conservation, communication development, and child protection. Playing a participatory-supervisory role was the fourth category and had two subcategories of participation and supervision.

Conclusion: Identifying the strategies used to play the mothering role can help health care professionals to support, provide advice, and train the mothers with breast cancer and their families. It also helps mothers to play their mothering role during the disease.

Keywords: Mothering role, Breast cancer, Qualitative study 


\section{راهبردهاى مورداستفاده مادران مبتلا به سرطان يستان براى ايفاى نقش مادرى: يك مطالعة كيفى}

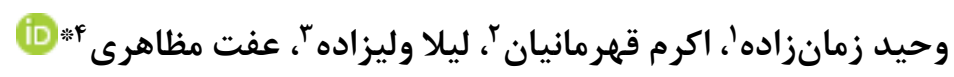

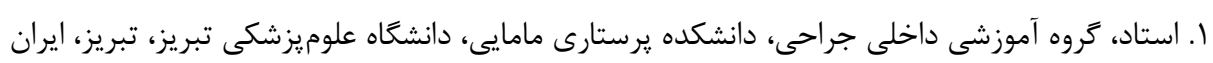

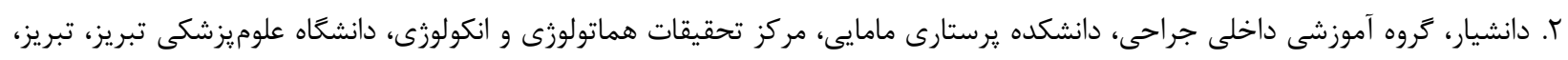

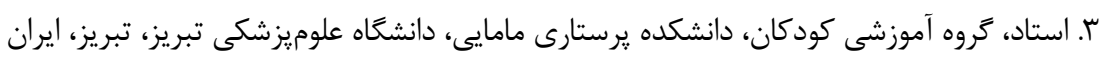

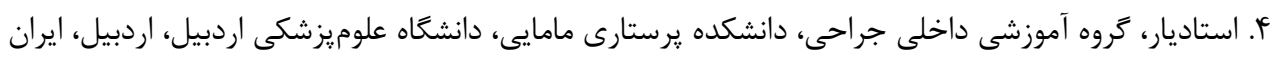

\begin{tabular}{|c|c|}
\hline جكيده & اطلاعات مقاله \\
\hline 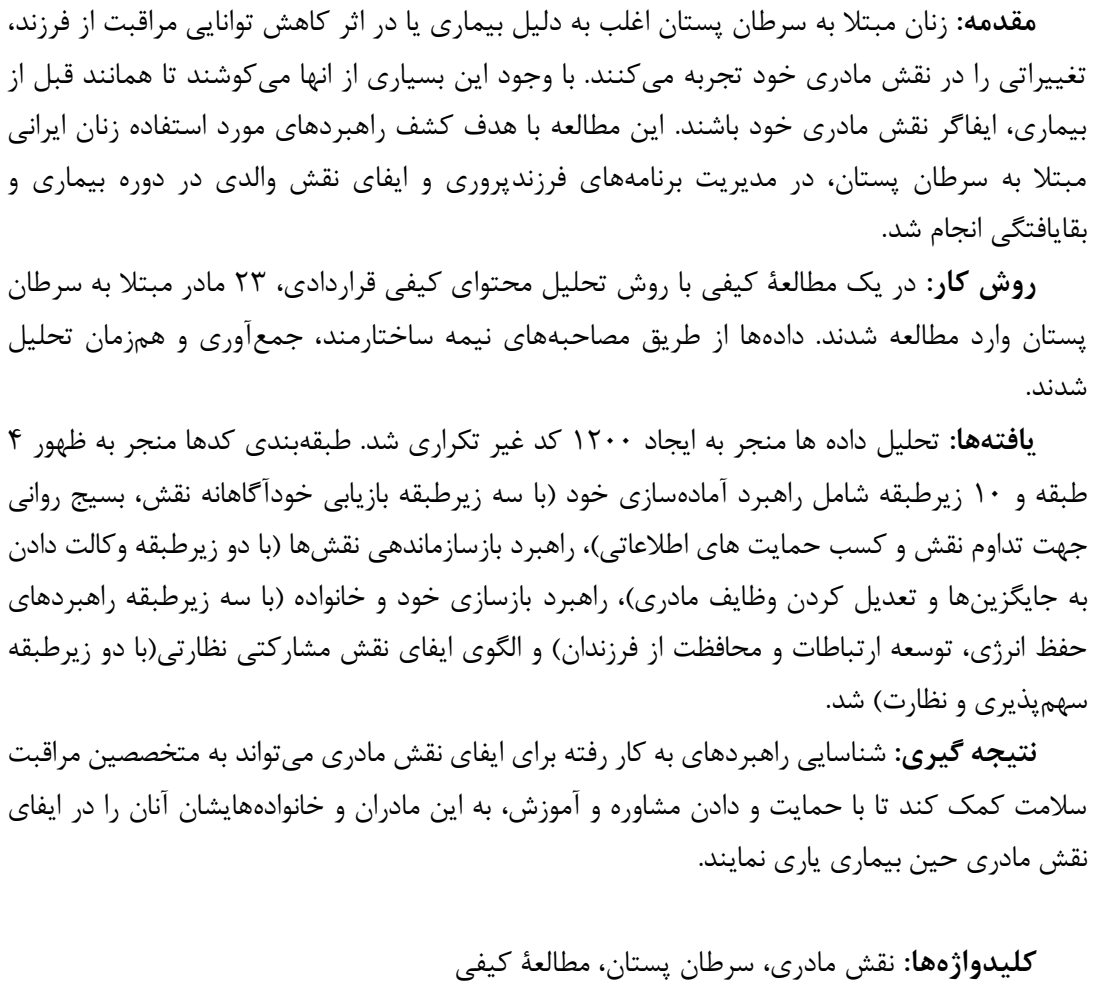 & 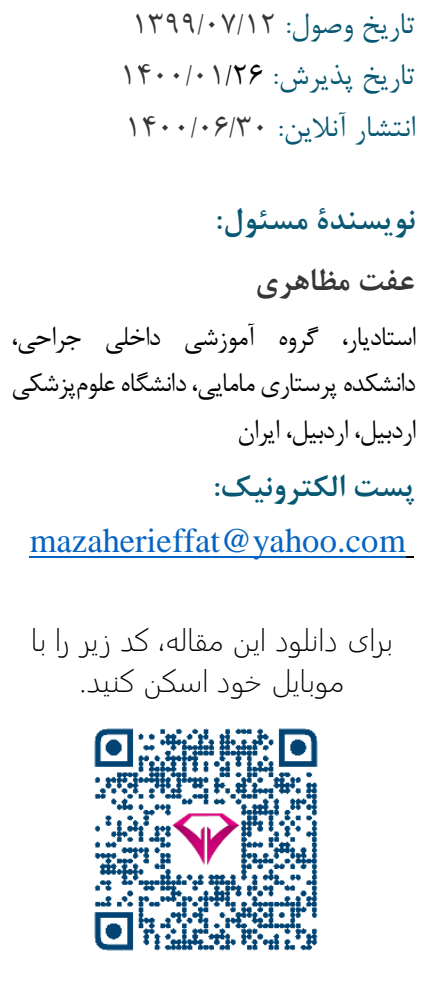 \\
\hline
\end{tabular}

كه مادر صلاحيت مورد نياز براى مراقبت از فرزند، عشق و

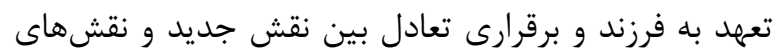

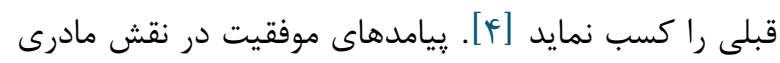
براى فرزند، رشد عاطفى و شناختى، دلبستخى، سلامتى و صلاحيت اجتماعى است [ب]. نقش مادرى در اثر ابتلا به بيمارى و از طريق كاهش اجت المات توانايى مراقبت از فرزند ممكن است تغيير يابد [هـ]. ابتلاى دادي زنان به سرطان يستان همزمان با ايفاى نقش مادرى، اثرات
سرطان يستان، شايعترين سرطان و ينجمين علت مرى در زنان ايرانى است [ [ ]. ميانگين سن بيماران در ايران، تقريباً

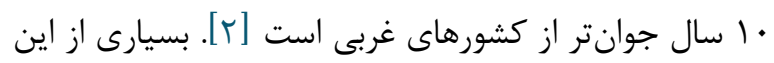
زنان در زمان ابتلا به سرطان يستان، ايفاگر نقش مادرى نيز

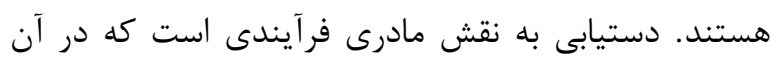

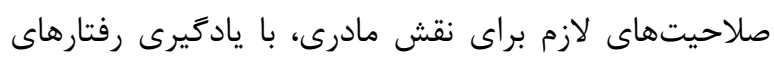

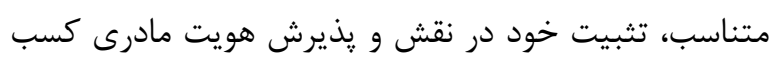

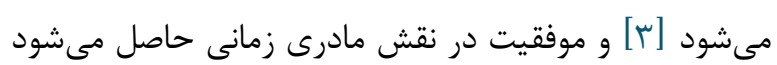




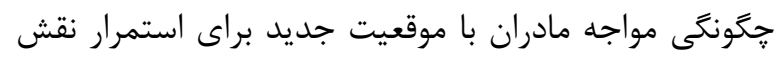

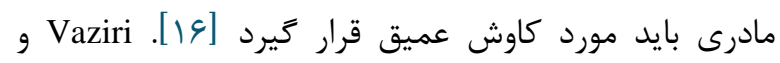

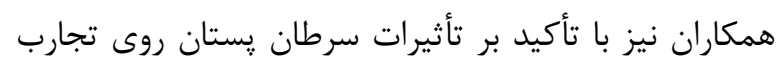

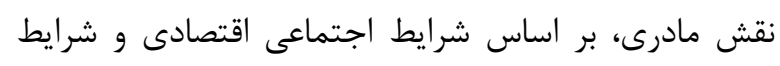

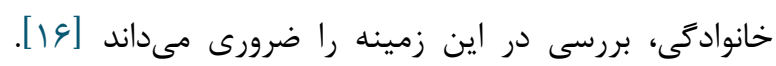

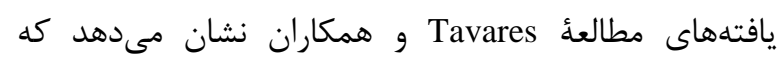

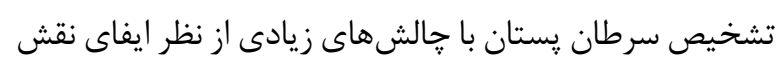

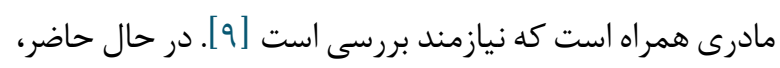

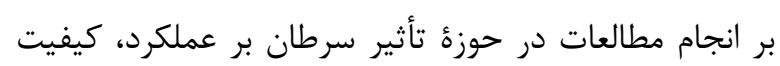

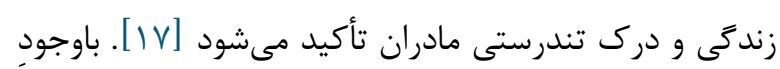

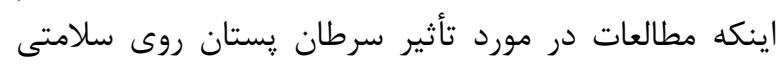

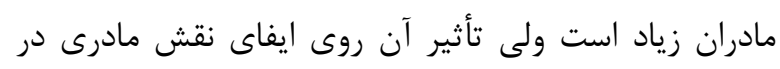

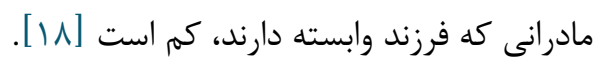

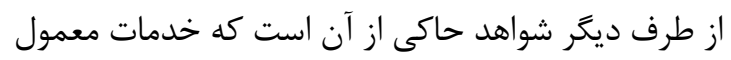

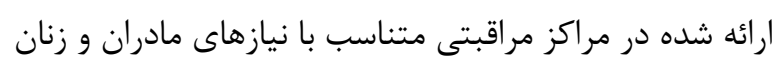

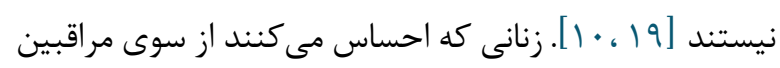

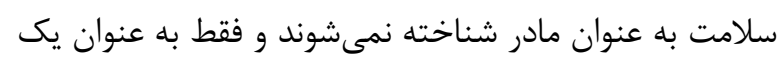

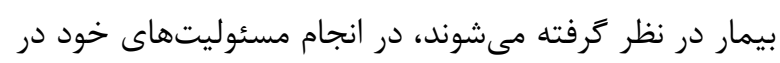

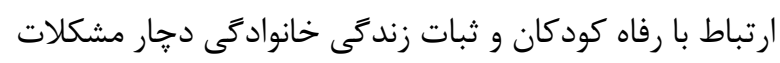

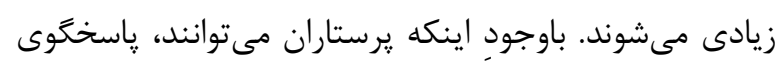

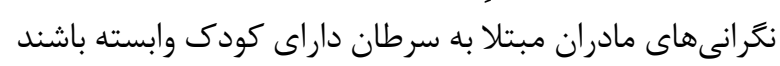

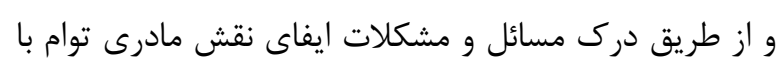
ابتلا به سرطان، در حمايت اجتماعى و وروانى از ائن اين بيماران

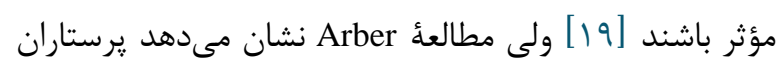

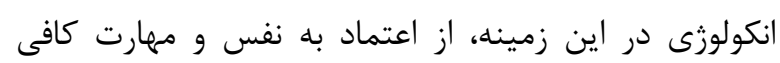

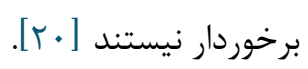
از آنجا كه يزوهش كيفى، داراى منشأ فلسفى انسان كرايانه

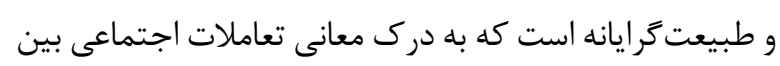

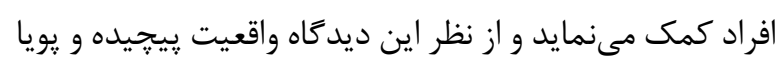

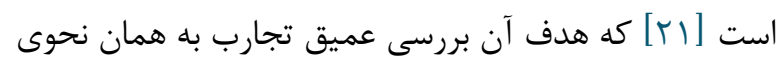

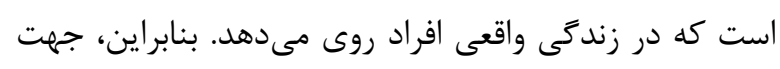

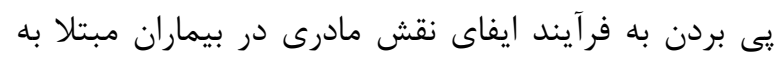

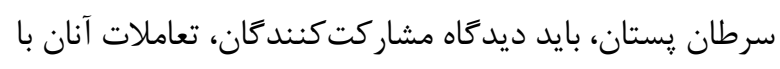

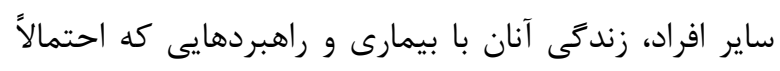

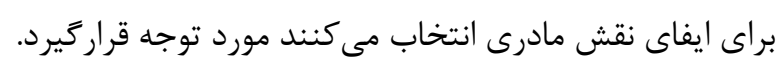

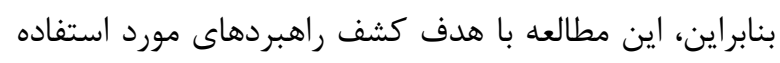

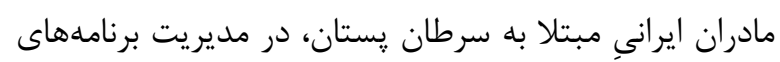

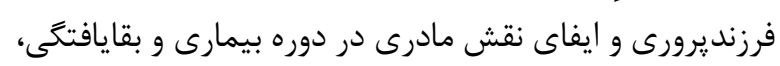

منفى بيمارى [ع] و مشكلات ناشى از مسئوليتهاى مراقبت

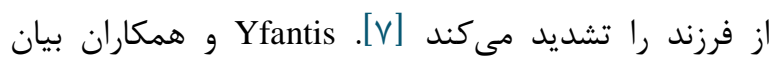

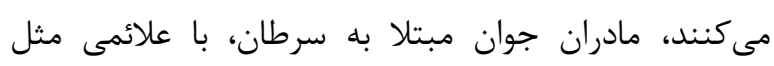

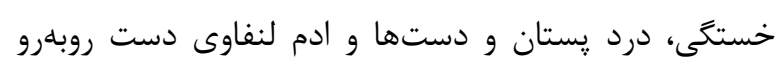

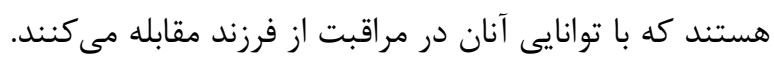

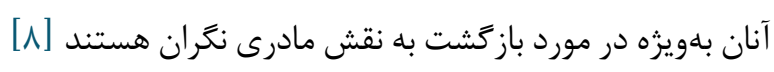

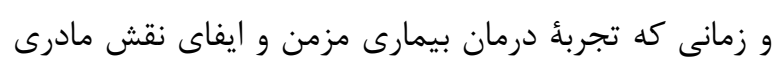

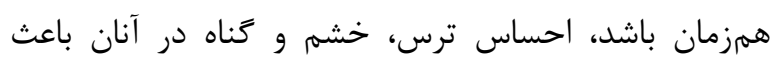

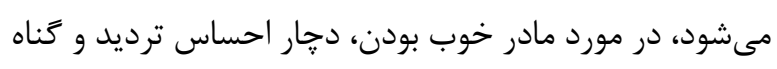

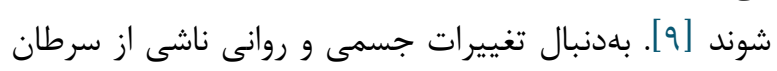
يستان و درمان آن، روابط اجتماعى و تعاملات صميمانه مادران

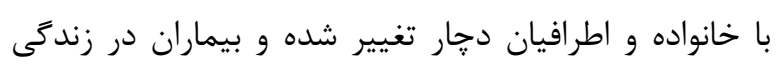

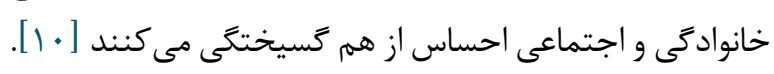
Mousvi Diva

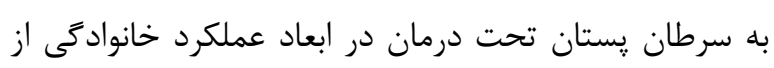

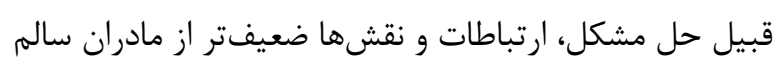

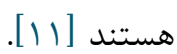

ناخئه Strickland

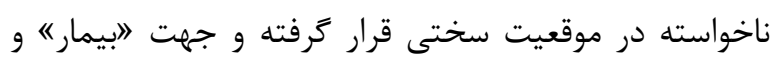

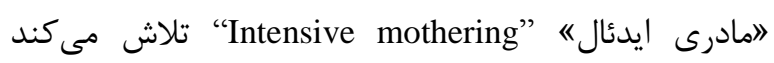

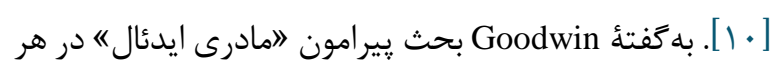

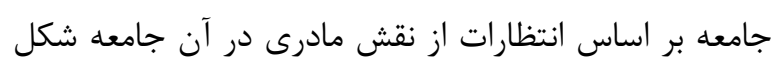

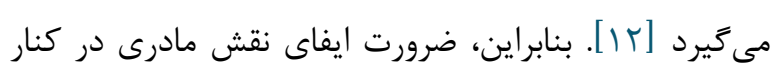

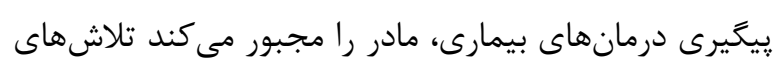

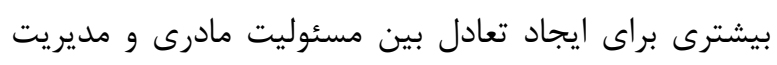

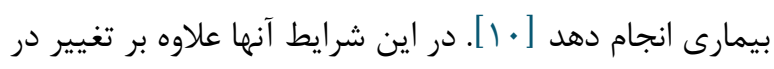

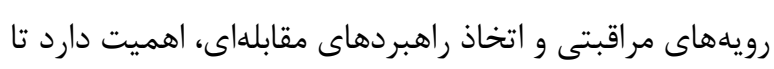

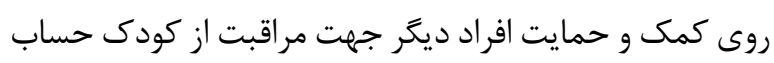

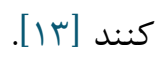

خانواده، نقش كليدى در به وجود آوردن محيط حمايتى

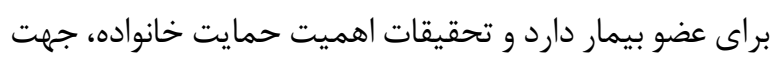

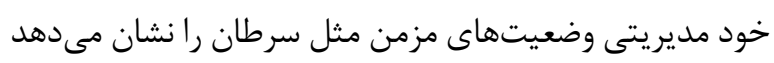

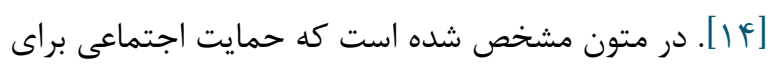

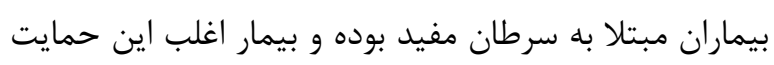

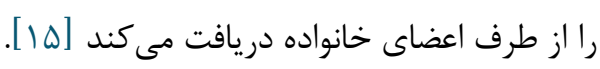

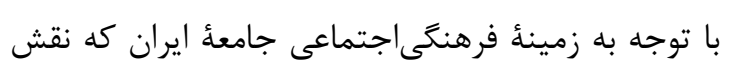

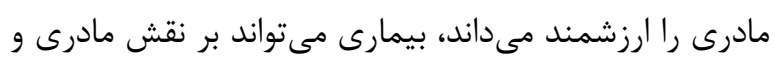

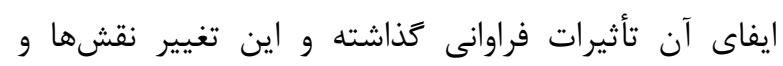


همه متن مصاحبهها كلمه به كلمه بازنويسى شدند و توسط

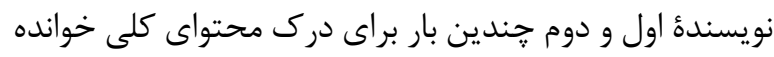

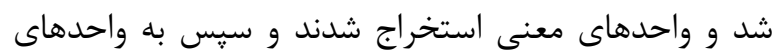

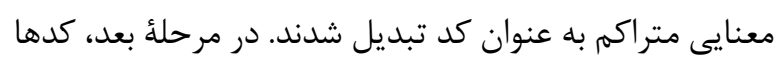
براى شباهتها و تفاوتها مقايسه شدند و زيرطبقات و طبقات

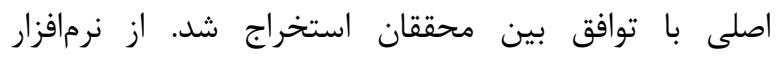
MAXQDA نسخه •| [سזr]، براى مديريت دادهان استفاده

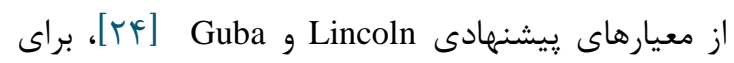

قابليت اطمينان يا ريكور مطالعه استفاده شد. اعتبار از طريق إنادي اختصاص زمان كافى به جمعآورى و تحليل دادهها، تعامل

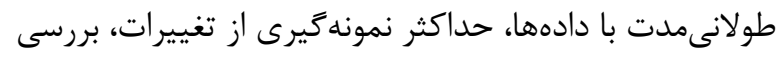

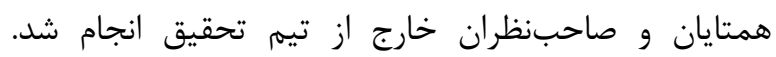

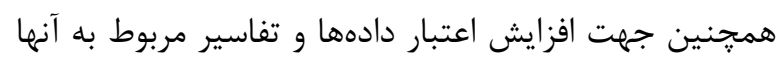
از קك كردن توسط مشاركت كنندكان (Member check)

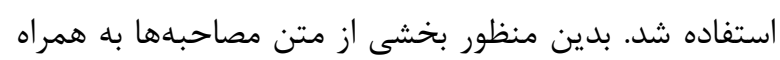

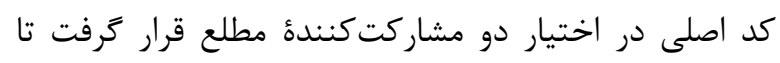

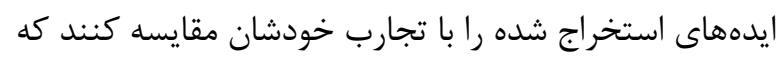

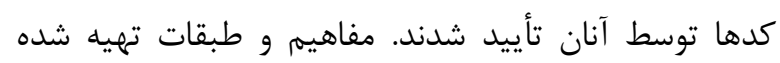
توسط ناظران و كارشناسان ماهر بررسى و بازبينى و تأييد

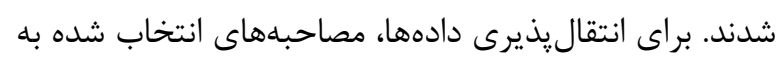

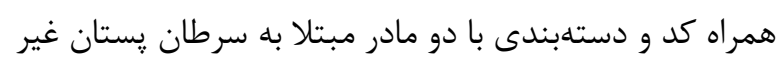

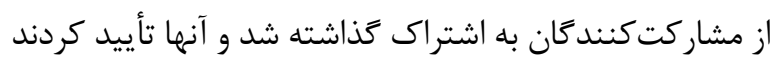

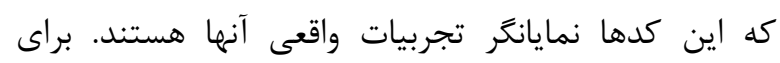

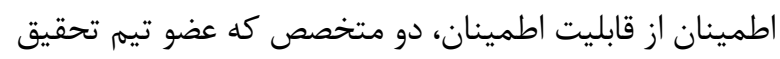
نبودند اما با مطالعات كيفى آشنا بودند، واحدهاى إنى معنايى،

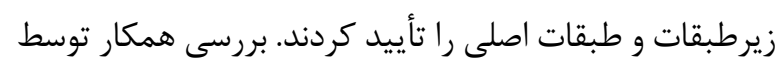

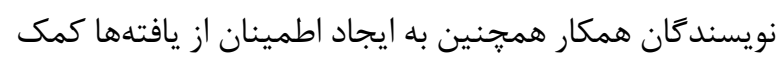

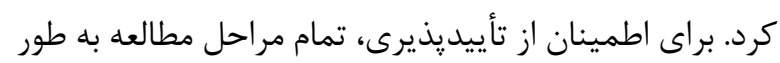
واضح به منظور حسابرسى خارجى مستند شدند.

\section{ملاحظات اخلاقى}

اين مقاله بخشى از نتايج رساله دكتراى يرستارى است كه از سوى معاونت تحقيقات و فناورى و كميته اخلاق دانشكاه علوميزشكى تبريز با كد اخلاق IR.TBZMED.REC 1396.1253.تصويب شده است. رضايت آكاهانه از همأ كلأ

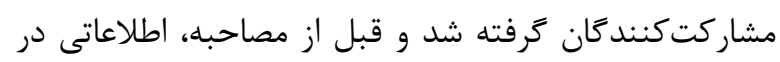
مورد هدف، روش مطالعه، محرمانه بودن دادهها، داوطلبن ماندانه
با رويكرد تحليل محتوا انجام شد تانتايج آن بتواند در شناسايى

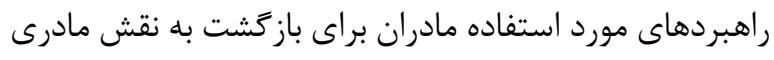

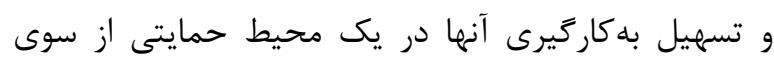
يرستاران، كمك كننده باشد.

\section{روش كار}

مطالعهُ حاضر، مطالعه كيفى از نوع تحليل محتواى كيفى

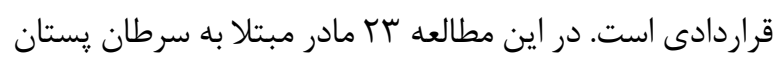

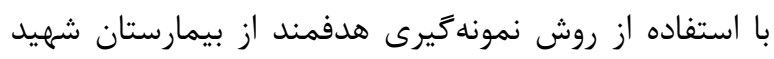

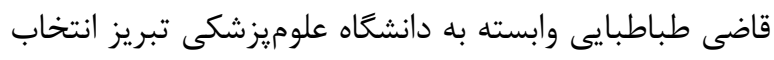

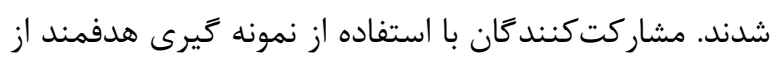

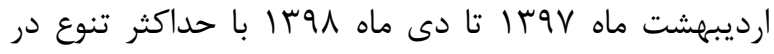
نمونهَيرى از نظر سن، سطح تحصيلات، نوع درمان و تعداه

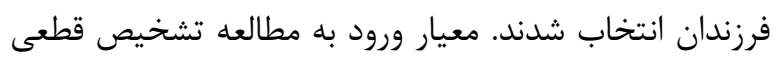

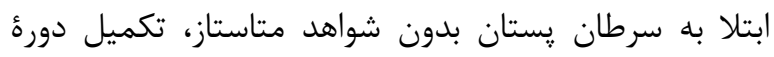

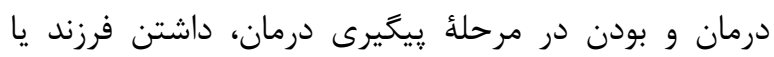

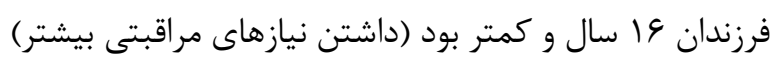

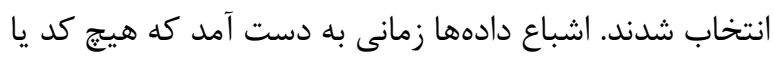

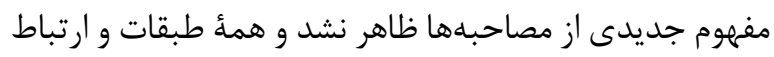

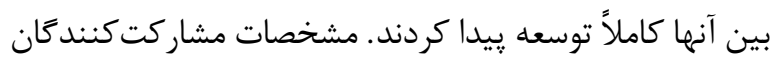
در جدول شماره ا ارائه شده است.

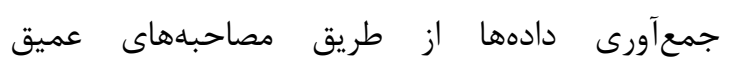

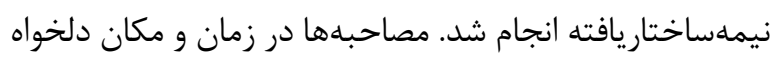

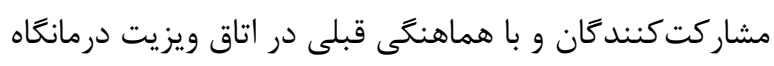

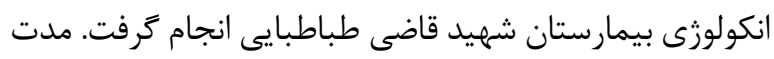

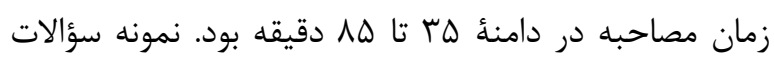

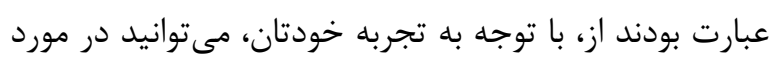

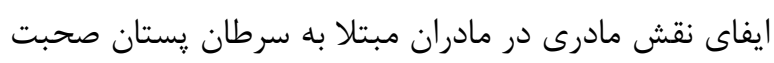

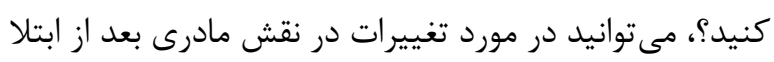

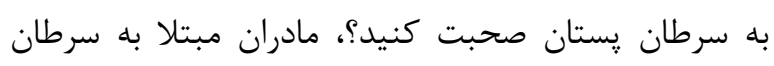

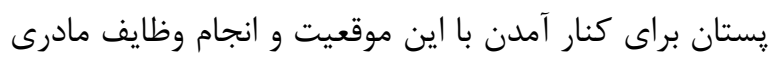

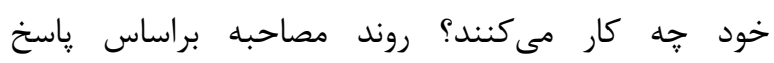

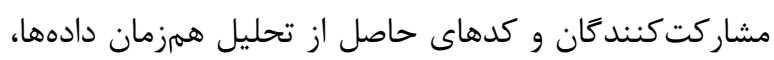

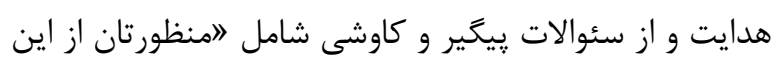

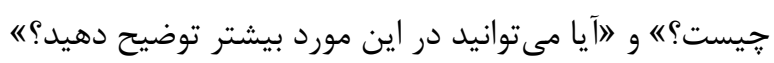
نيز استفاده مىشد.

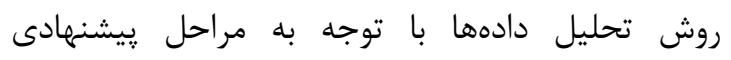

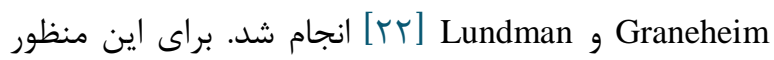

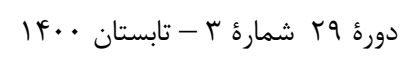


اطلاعاتى)، راهبرد بازسازماندهى نقشها (با دو زيرطبقه وكالت دادن به جايكزينها و تعديل كردن وظايف مادرى)،راهبرد بازسازى خود و خانواده (با سه زيرطبقه راهبردهاى حفظ انرئ ناري،

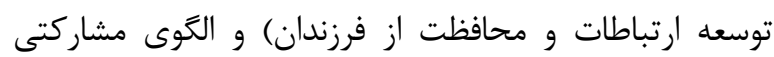
نظارتى (با دو زيرطبقه سمهريذيرى و نظارت) شد كه مادران

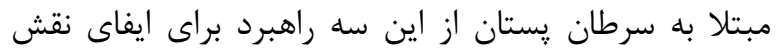

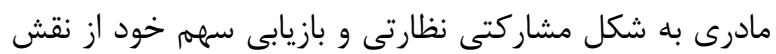

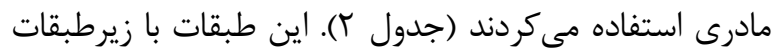
آنها در ادامه توضيح داده شده است.
بودن شركت در مطالعه و آزادى كنارهگيرى مشاركت كنندگان در مطالعه در اختيار آنها قرار كرفت.

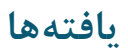

تحليل دادهاى حاصل از مصاحبه با بr مادر مبتلا به

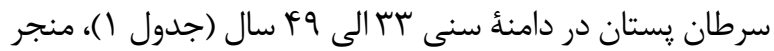

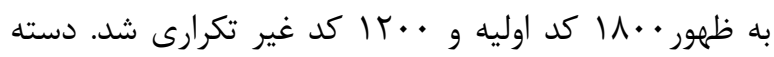

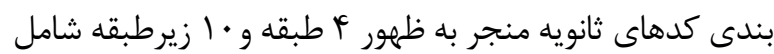
راهبرد آمادهازى خود (با سه زيرطبقه بازيابى خودآكاهانه نقش، بسيج روانى جهت تداوم نقش و كسب حمايت هاى

جدول شماره ا. مشخصات فردى اجتماعى مادران مشاركت كننده در مطالعه

\begin{tabular}{|c|c|c|c|c|c|c|c|c|c|c|c|}
\hline مصاحبه & مصاحبه & ساكن & | لدرمان هاى انجام شده & مدات ابتلا به & شغل همسر & شغل مادر & تحصيلات & فرزند & فرزندان & مادر & رديف \\
\hline 1 & GF & تبريز & ماستكتومى يكطرفه و & $\Delta$ & رانده & خانه دار & بيسواد & 1 & r & $4 q$ & 1 \\
\hline$r$ & $\Delta \cdot$ & 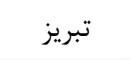 & ماستكتومى يكطرفه & ir & 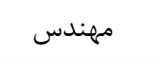 & يزشك & فوق تخصص & r & r & rq & $r$ \\
\hline 1 & $\Lambda F$ & تبريز & ماستكتومى يكطرفه و & IT & مهندس & خانه دار & 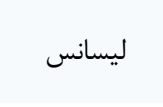 & 1 & 1 & rV & $r$ \\
\hline 1 & r. & 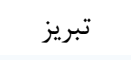 & ماستكتومى يكطرفه & 9 & 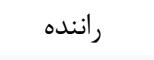 & خانه دار & راهنمايى & r & r & pq & f \\
\hline 1 & r. & مياندوآب & ماستكتومى راديكال يكطرفه & $1 / \Delta$ & 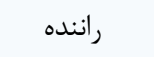 & خانه دار & ابتدايى & 1 & r & er & $\Delta$ \\
\hline 1 & $\Delta \cdot$ & 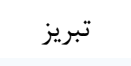 & ماستكتومى راديكال يكطرفه & 4 & 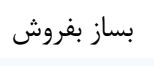 & خانه دار & سيكل - & 1 & r & iv & $q$ \\
\hline 1 & rT & 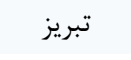 & ماستكتومى يكطرفه & TF & آ آزاد & خانه دار & 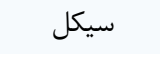 & 1 & r & rq & $v$ \\
\hline 1 & $i \Delta$ & بناب & ماستكتومى دو طرفه و & $\Lambda$ & كابينت ساز & خانه دار & ينجم ابتدايى & 1 & $r$ & rᄉ & $\Lambda$ \\
\hline 1 & f. & تبريز & ماستكتومى دو طرفه & f & وسايل صوتى كار & خانه دار & بيسواد & 1 & r & i) & 9 \\
\hline 1 & rt & بستان آباد & ماستكتومى يكطرفه & r & كاركر & خانه دار & ينجم ابتدايى & 1 & r & il & 1. \\
\hline 1 & ro & 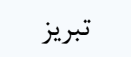 & ماستكتومى يكطرفه & $\wedge$ & & خانه دار & راهنمايى & 1 & r & r. & 11 \\
\hline 1 & 19 & تبريز & ماستكتومى يكطرفه و & TF & كارگر & خانه دار & ينجم ابتدايى & $r$ & r & rV & ir \\
\hline 1 & r. & ت ت تبريز & ماستكتومى راديكال يكطرفه & TY & 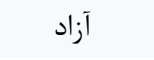 & خانهدار & ديڤلم & 1 & r & r & r \\
\hline 1 & 4. & 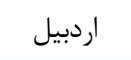 & ماستكتومى يكطرفه & TY & 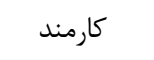 & 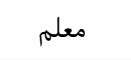 & 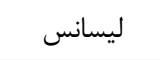 & 1 & r & rq & if \\
\hline 1 & 4. & 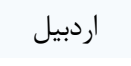 & ماستكتومى يكطرفه & 4 & 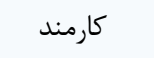 & معلم & فوق دييلم & r & r & سץ & 10 \\
\hline 1 & ro & 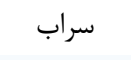 & ماستكتومى يكطرفه & $\wedge$ & آ آزاد & خانهدار & ديبلهم & 1 & r & is & 19 \\
\hline 1 & $\Delta \Lambda$ & 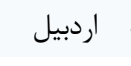 & ماستكتومى راديكال يكطرفه & IT & 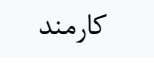 & 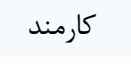 & فوق دييلم & 1 & r & FT & IV \\
\hline 1 & $\Delta \cdot$ & اردبيل & ماستكتومى يكطرفه & Ir & كارمند ارتش & 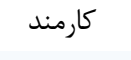 & دييلهم & 1 & $r$ & $4 q$ & 11 \\
\hline 1 & $\Delta \cdot$ & 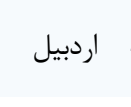 & ماستكتومى راديكال يكطرفه & Ir & 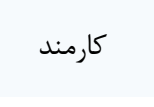 & 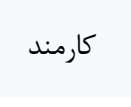 & كارشناس & 1 & r & rq & 19 \\
\hline 1 & f. & 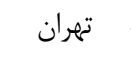 & ماستكتومى راديكال يكطرفه & ir & كارمند & آرايشكر & فوق دييلم & 1 & 1 & id & $r$. \\
\hline
\end{tabular}




\begin{tabular}{|c|c|c|c|c|c|c|c|c|c|c|c|}
\hline مصاحبد & مصاحبه مدت & ساكن & درمان هاى انجام شده & مدات ابتلا بها & شغل همسر & شغل مادر & تحصيلات & فرزند & فرزندان & مادر & رديف \\
\hline r & Fr & 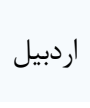 & ماستكتومى راديكال يكطرفه & v & 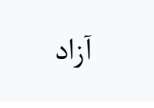 & 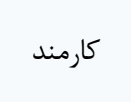 & كارشناسى & 1 & $r$ & rV & r) \\
\hline 1 & $r$. & اردبيل & ماستكتومى يكطرفه & $\wedge$ & كارتر & خانه دار & راهنمايى & 1 & 1 & iq & rr \\
\hline 1 & $v \cdot$ & ت ت تهران & ماستكتومى يكطرفه & IT & بازنشسته & معلم & دبيرستان & 1 & r & iv & r \\
\hline
\end{tabular}

جدول شماره r: طبقات و زيرطبقات فر آيند ايفاى نقش مادرى در مادران مشاركتكننده در مطالعه

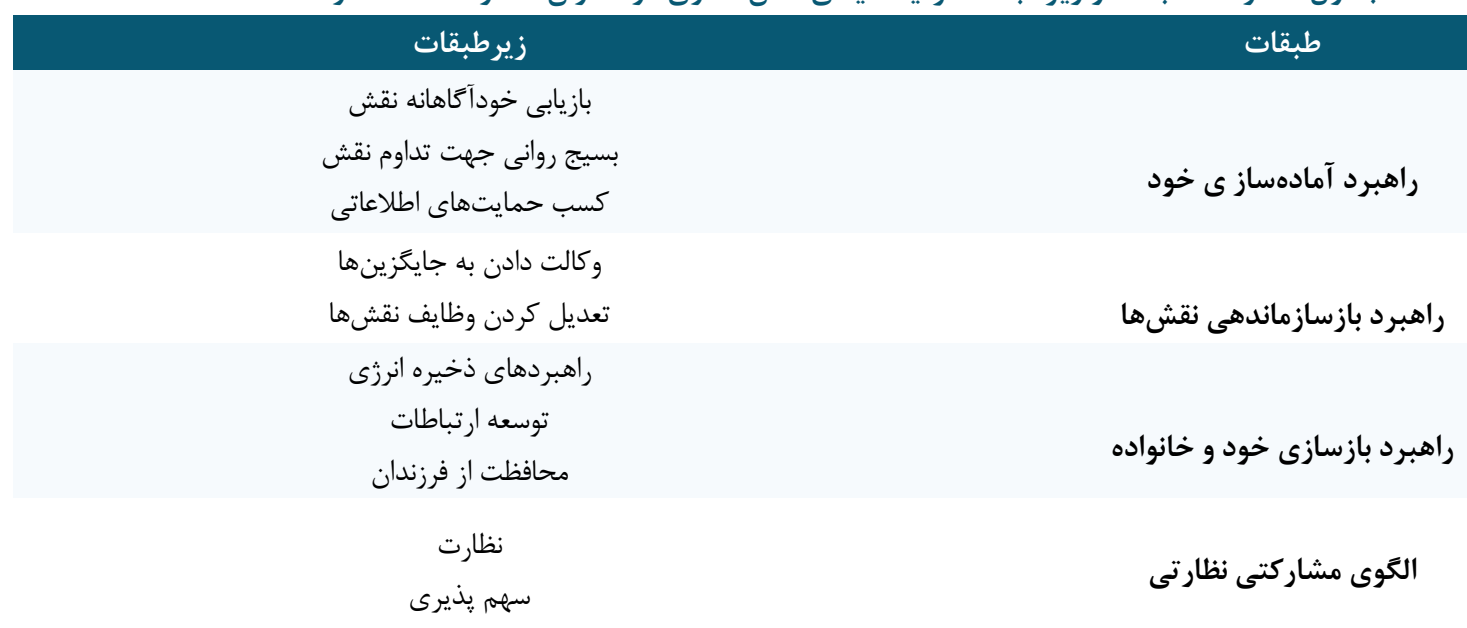

مادران نقاط قوت و ضعف خود را مىشناختند و به تأثيرى كه مىتوانستند در اطرافيان جهت جلب مشاركت آنان در انجام وظايف مادرى داشته باشند، آحاه بودند.

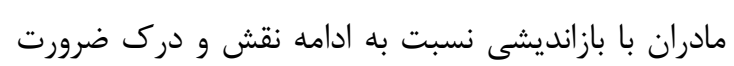

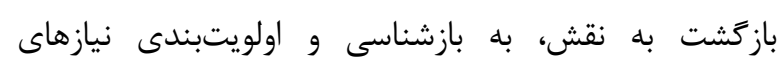

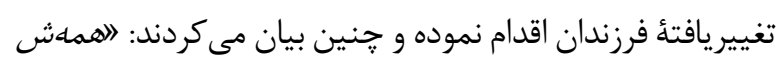

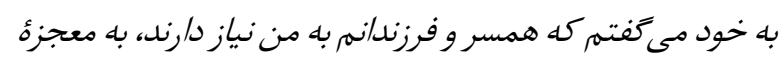

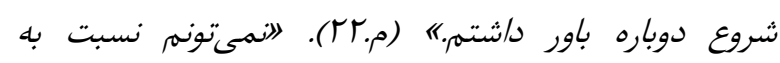

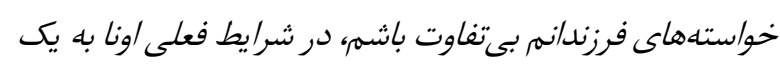
مادرفداكار نياز دارن، بايد دوباره سر يا بشهم" (م. بَ).

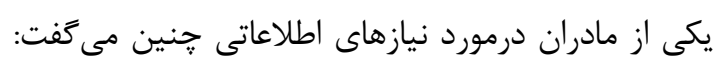

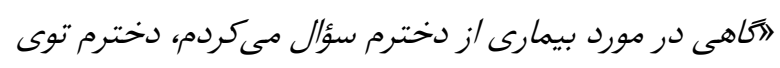

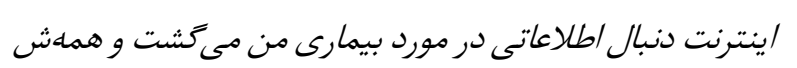

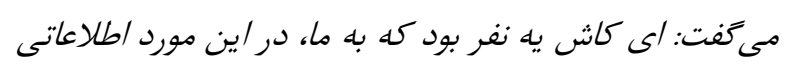

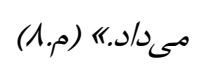

مادران درك كردند كه بايد به نيازهاى تغيير يافته عاطفى،

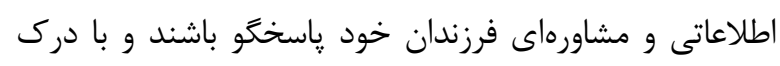
حساسيت ايفاى نقش مادرى به اين آكاهى رسيدند كه جهت

\section{طبقه ا: راهبرد آمادهسازى خود}

مادران در تلاش بودند با برنامهريزى و سازماندهى در انجام وظايف مادرى، خودشان را براى موقعيت به وجود آمده و تغييراتى كه در ايفاى نقش مادرى بعد از بيمارى رخ داديف داده است،

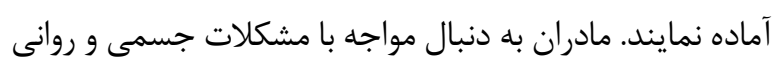

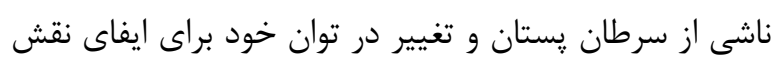
مادرى، به اين درك مىرسيدند كه حفظ تداوم نقش مادرى و

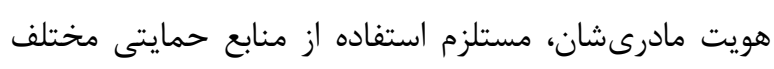

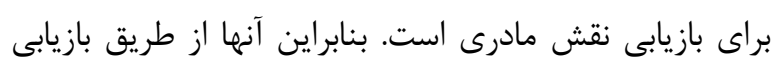

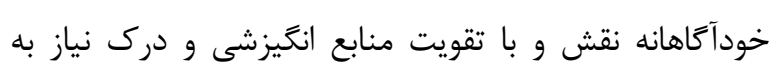
حمايت اطلاعاتى، جهت كسب دانش از منابع متعدد اطلاعاتى

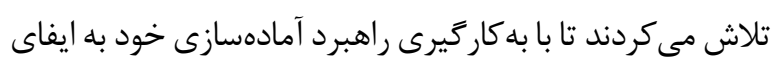

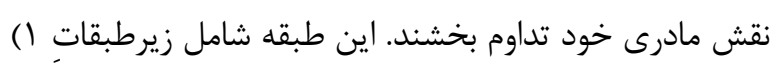

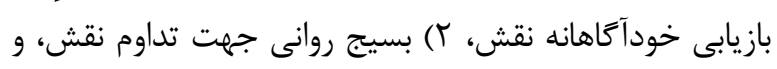
ب) كسب حمايتهاى اطلاعاتى بود. 1-1- بازيابى خود آكاهانٔ نقش

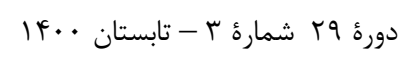


"زمانى كه حين درمان بيمارى به دخترم شير مىدادم،

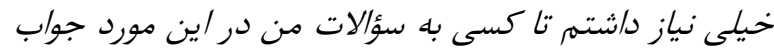

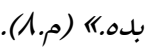

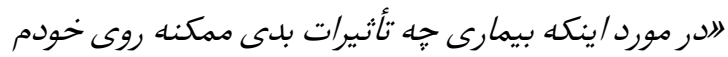
و بجهها بذاره، اطلاع زيادى ند/شتمر وزمانى كه درمانكاه مىرفتمه

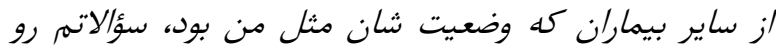

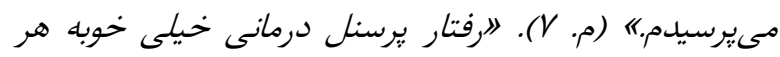

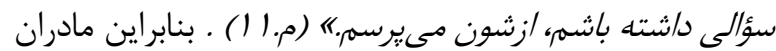

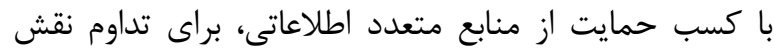
مادريشان همزمان با بيمارى تلاش مى مكردند. طبقه r: راهبرد بازسازماندهى نقشهان مادران درصدد بازسازى هويت و نقش مادرى خود بودند كه با ابتلا به سرطان يستان آسيب ديده بود. مادران براى باز

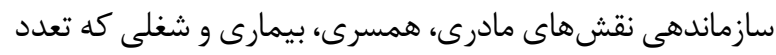

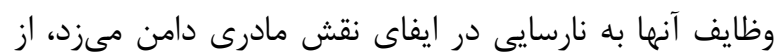
راهبردهاى وكالت دادن به جايكزينها و تعديل كردن وظايف نقشها استفاده مى كردند، اين راهبردها عدم تعادل و فشار نقش دان را كاهش و به تداوم نقش مادرى كمك مى كردند. اين طبقد شامل زيرطبقات () وكالت دادن به جايكزينها و r) تعديل كردن وظايف نقشها بود.

\section{ا-r-وكالت دادن به جايكزينها}

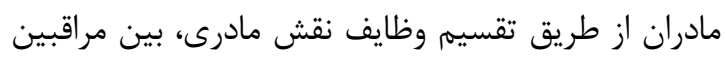
جايكزين ( براى مثال فرزندان ارشد دختر و خواهران خود) كه به صورت هستههاى ياريخرى خودجوش، براى كمكى به تداوم

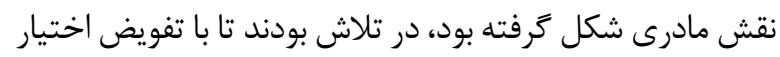
توأم با نظارت، قادر به تداوم نقش مادرى شوند. مادران براى توسعه برخى مهارتهاى عملى در فرزندان، از منابع خارج از

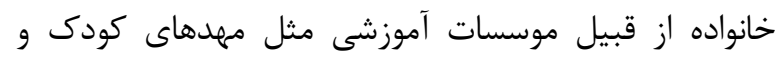

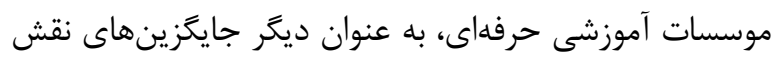
استفاده كردند و جنين بيان مى كردند:

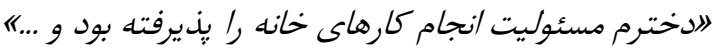

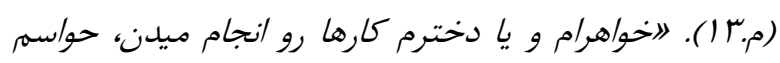

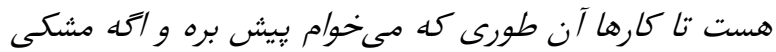

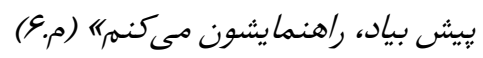

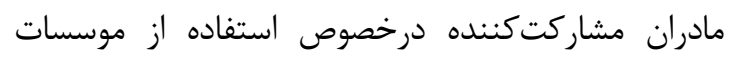
آموزشى، خدماتى ارفاهى به عنوان مراقبين جايكزين جنين بيان مى كردند: المهدكودكى كه فرزندانم را جهت آموزش و نكادهارى

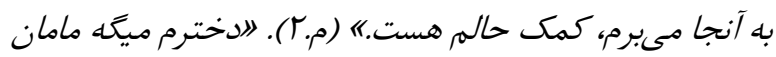

برآوردن نيازهاى تغيير يافته فرزندان، ايفاى نقش مادرى شان بايد با جلب حمايت از اطرافيان انجام شود.

\section{r-1- بسيج روانى جهت تداوم نقش}

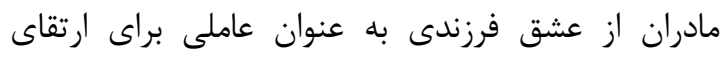

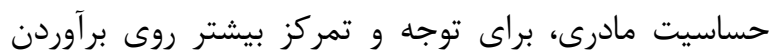
نيازهاى فرزندان خود سود بردند. مادران با مديريت كردن خستكى روانى و بى حوصلكى خود توانستند، تمركز ذهنى لـانى لازم براى هماهنگى برنامههاى مراقبتى فرزندان خود را را به دست آورند و جنين بيان مى كردند:

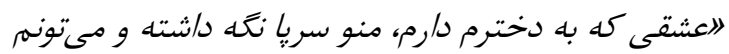
در /ين شرايط سخت، ازش مراقبت كنه/ (م.ها). لابراى جلوكيرى /ز حواسيرتى، هر روز برنامه مىنويسه، مثلاً امروز

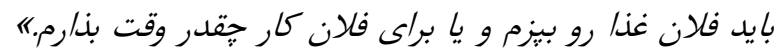

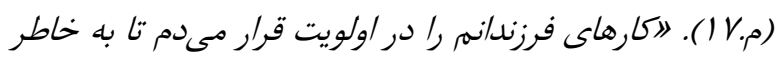
بى حوصلكى به تاخير نيفته، كارهاى غير ضرورى را حذف كران كردم

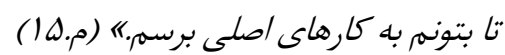
حمايت اعضاى خانواده و اطرافيان نيز به عنوان مشوقى بران براى إنى

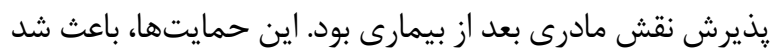

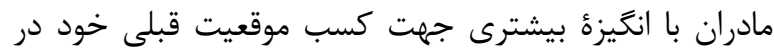

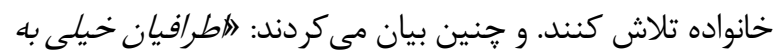

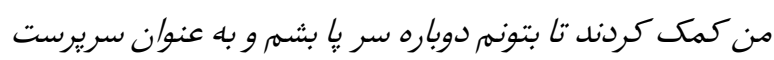
خانواده، هم بر بيمارى غلبه كنم و همم شغلم رو ادامه بلدم."

بنابراين مادران مشاركت كننده در مطالعه اقدام به بسيج

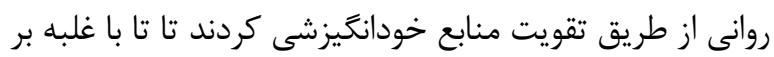
استرس خود انخيزش و اعتمادبهنفس لازم را جهت برآوردن

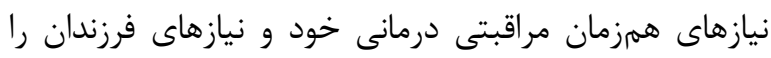

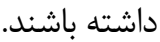

\section{r-1 - كسب حمايت اطلاعاتى}

حمايتهاى اطلاعاتى، به عنوان يكى از انواع منابع حمايت

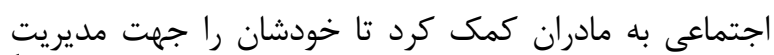

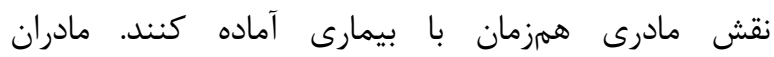
مشاركت كننده، به دليل عدم آكاهى در مورد تأثير عوارض بيمارى و درمان در خود و اعضاى خانواده، نياز به حمايت

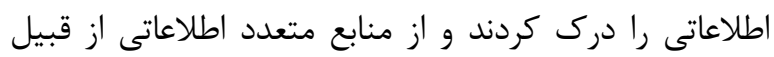

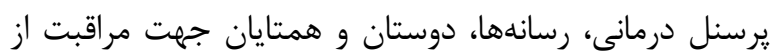
فرزندان كسب اطلاعات كردند و اينكونه بيان مى كردند: 
و تغيير نحوه انجام كارها، انرزى خود را براى مقابله با موانع ايفاى نقش مادرى، ذخيره مىنمودند و جنين بيان مىكردند:

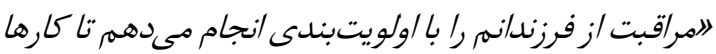
با كمترين خستكى انجام بشه، بعضى جيزها رو تغيير دادم، هفتهاى يك بار خونه رو جاروبرقى مى كشهم. با استراحت كردن

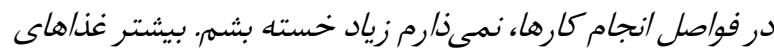

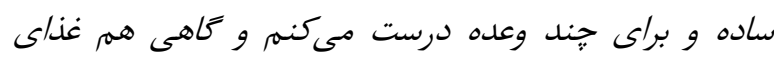

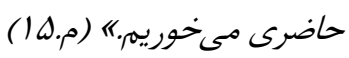

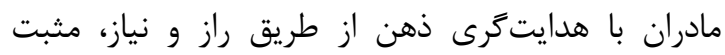

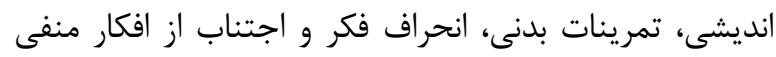

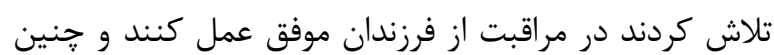

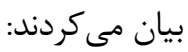
"همهش در حال ذكر هستهم و مى دانم خداوند مهربان به

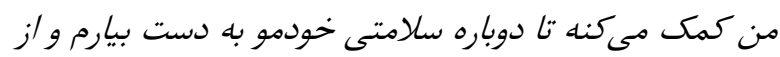
بجهها مراقبت كنم." (م.م. IV). لدر حال استراحت، عضلات بلدنم

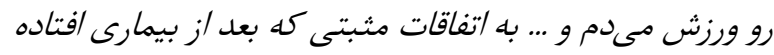

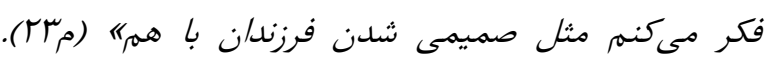

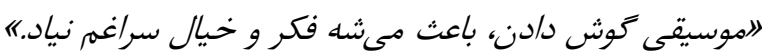
راهبردهاى ذخيرء انرزى به مادران كمك كرد تا با غلبه بر

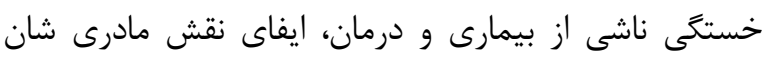

$$
\text { متناسب با توانايى جسمى و روانى باشد. }
$$

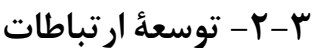

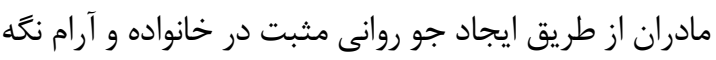

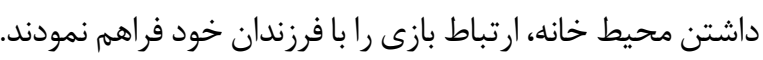
آنان با ايجاد موقعيت همبازى شدن فرزندان با ديكر كودكان و كيفىسازى فعاليتهاى تفريحى، تعاملات فرزندان را با ديخران توسعه مى دادند و جنين مى كَفتند: "اتلاش مى كنمه جَوخونه روآرامنَّه دارم، برنامه ها راطورى

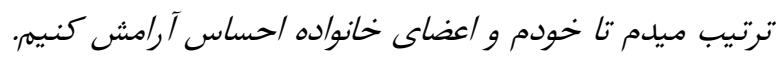

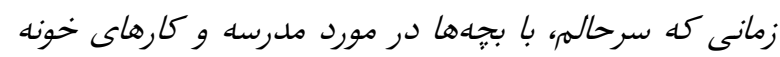

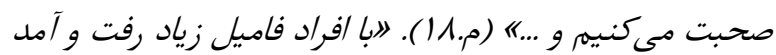

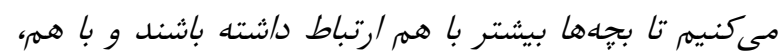

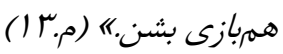
مادران در مورد كيفىسازى فعاليتهاى تفريحى جنين

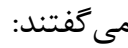
"بجهمام رو نمىتونستهم زياد براى كردش بيرن بيرون ببرم، يدرشان حياط بساط كباب راه مىندازه و... به جاى بيرون بيرون رفتن بيرون
به من آشيزى ياد بله ولى من حوصله ندارم و ... اونو در كلاس آشيزى ثبت نام كردم. (م. (V) مادران از طريق وكالت دادن به جايكزين ها و تفويض اختيار توام با نظارت در صدد سازماندهى نقش هاى مان مادرى بودند تان بتوانند با فعاليت موازى با جايكزينها، وضعيت را ساماندهى

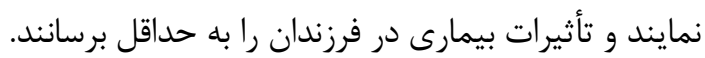

\section{r-r- تعديل كردن وظايف نقش}

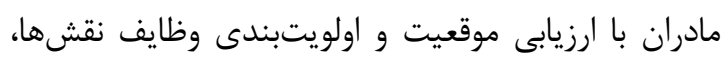
سعى كردند تمركز كافى در مراقبت از فرزندان داشته باشند،

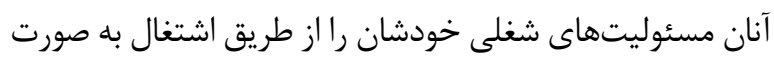

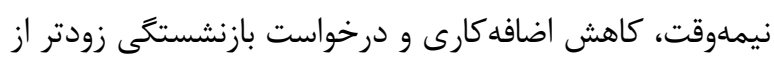

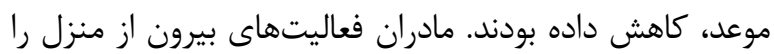

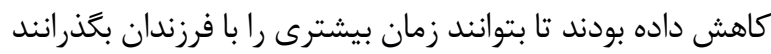

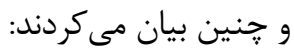
"اتصميم كرفتهم به صورت نيمهوقت كار كنهم و اضافهكارى

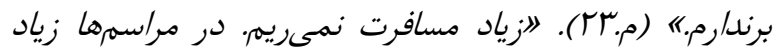
شركت نمىكنه، تلاش ميكنهم دجار خستكى نشمه تا بتونم

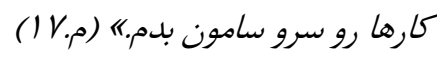
تعديل كردن وظايف نقشها راهبردى بود كه مادران با

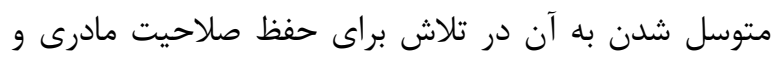
تداوم نقش مادرى به عنوان مادر عادى بودند.

\section{طبقه ז: راهبرد بازسازى خود و خانواده}

بازسازى، فرآيند ساختن يا خلق كردن دوبارئ جيزى است

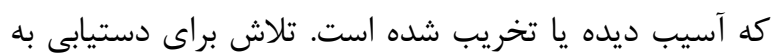

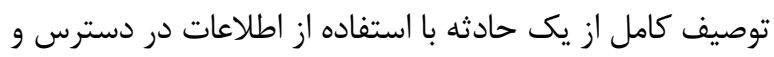
يا تلاش براى برقراى مجدد آنجه، طى حادثاى آسيب ديده

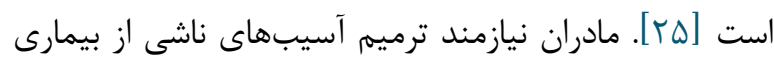

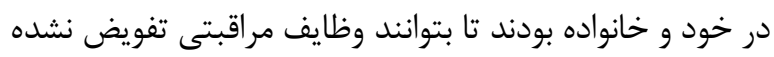

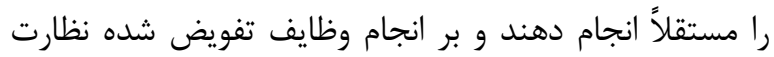

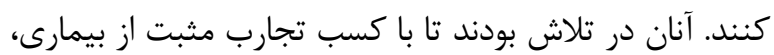

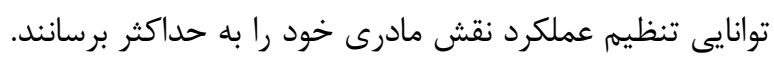

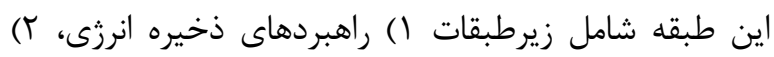
توسعه ارتباطات و ؟) محافظت از فرزندان بود.

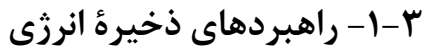

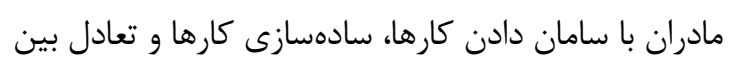

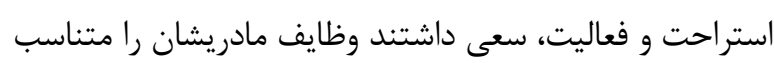
با توان جسمى خود انجام دهند و با حذف كارهاى غير ضرورى

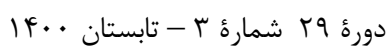




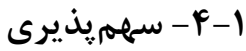

مادران از طريق برنامهريزى براى بازيابى نقش و دركيرشدن فعال در نقش تلاش كردند، به انتظارات از نقش مادرى ياسخ

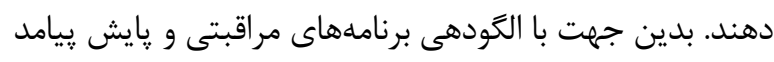

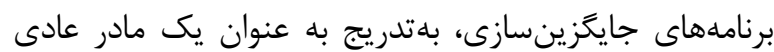

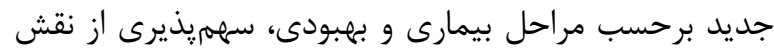

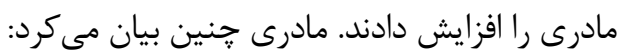

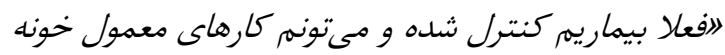

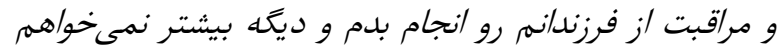

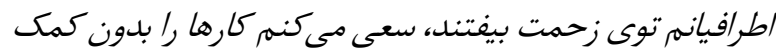

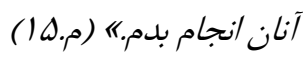

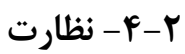

مادران ازطريق تصميم گيرىهاى مشاركتى با جايكزينها همجنين با الكودهى برنامههاى مراقبتى و وِايش رِيامد

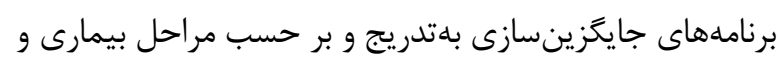

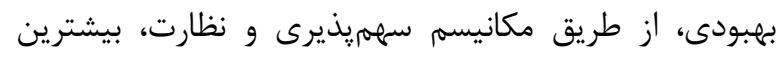
سهميذيرى از نقش مادرى را با كمترين نظارت بر مراقبين

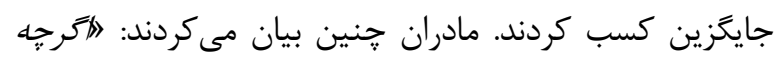

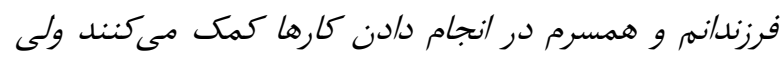
هميشه حواسم هست تا كارها درست و بهموقع انجام بشه.

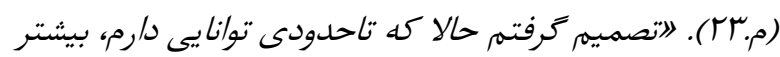

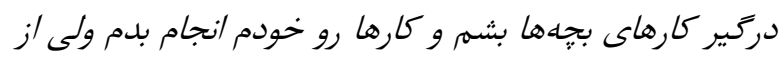
كمك اطرافيانم هم /ستفاده كنهم تا مراقبت /ز فرزندانم روى بنى

$$
\text { برزامه منظمه بيش بره." ( م."r) }
$$

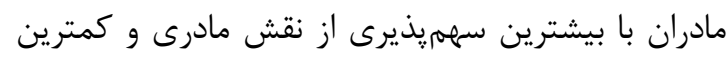

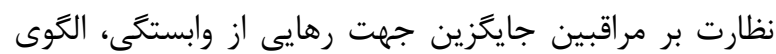
مشاركتى نظارتى را براى حفظ تعادل در عملكرد و ارتقاى سلامت خود و خانواده به كار ترفتند.

\section{بحث}

در پِاسخ به اين سؤال كه راهبردهاى مورد استفادئ مادران

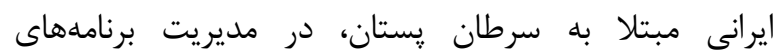

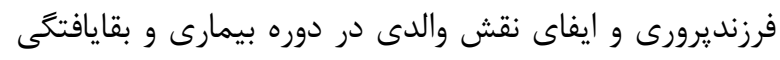
جيست؟ جهار طبقه و ده زيرطبقه ظاهر شدند.

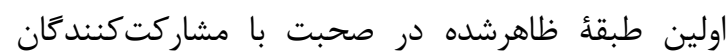

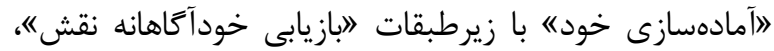
"ابسيج روانى جهت تداوم نقش" و "اكسب حمايتهاى
در اكثر مواقع بجهها رو توى حياط خونه سركرم مىكنيه."

مادران با برقرارى ارتباطات باز با فرزندان و توسعه ارتباطات با اطرافيان بر محدوديتهاى بيمارى كه منجر به به كاهش همراهى فرزندان در موقعيتهاى اجتماعى و اجتماعى شدن بـان آنان شده بود، غلبه مى كردند.

\section{r-r- - محافظت از فرزندان}

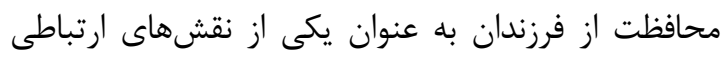

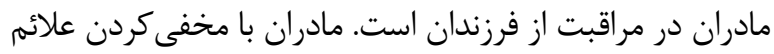

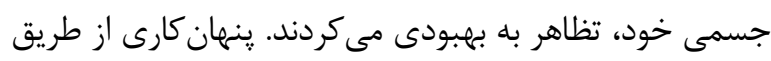

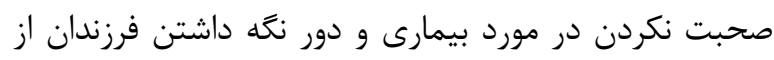

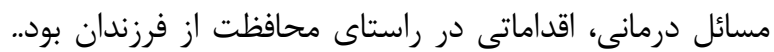
مادران جنين بيان ميكردند:

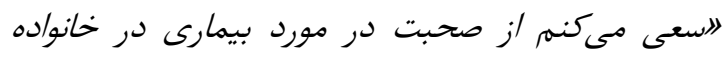

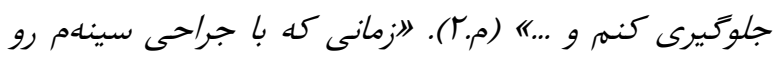
برد/شتند، خيلى مراقب بودم، بجهها متوجه /ين موضوع نشن.

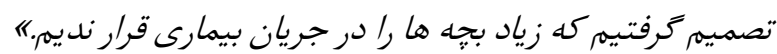

مادر ديكر در خصوص محافظت از فرزند جنين مى گفت:

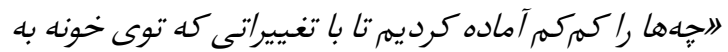

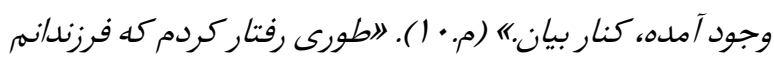

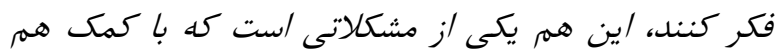

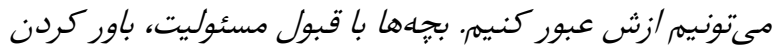
كه توانايى انجام كارهاى بيشترى رو دارن." (م. Tr. (T) مادران با افزايش دادن قدرت تابآورى فرزندان از طريق إنقايق

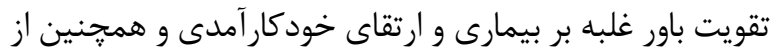

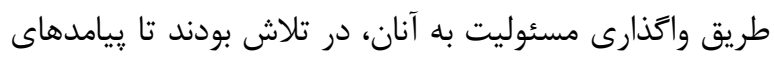

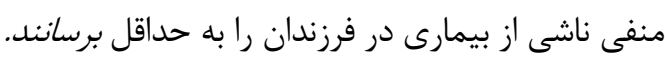

\section{طبقه f: الكوى ايفاى نقش مشاركتى نظارتى بئى}

مادران جهت تداوم نقش مادرى خود، با كسب حمايت از

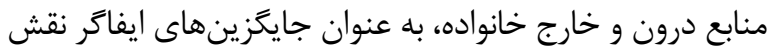

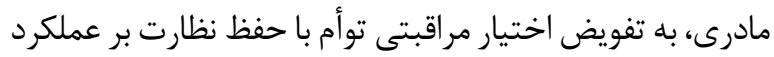
جايكزينها اقدام كردند و با استفاده از مكانيسم سهمريذيرى نظارت در تلاش جهت بازيابى نقش مادرى خود بودند و

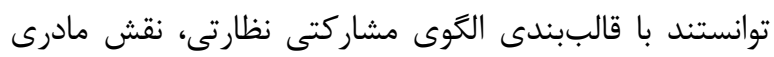
خود را به عنوان مادرى عادى جديد، تداوم بخشند. اين طبقيه

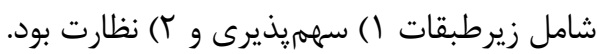




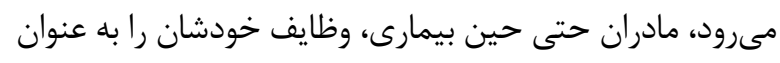

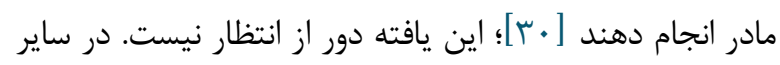

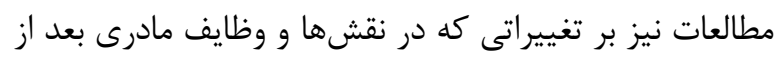

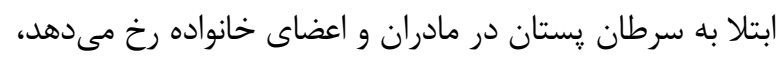

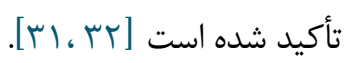

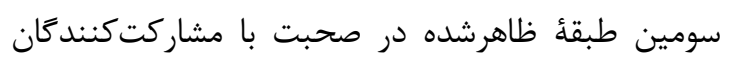

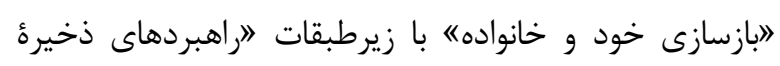

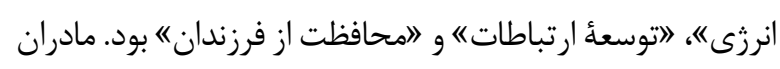

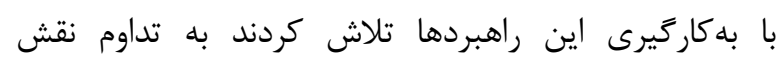

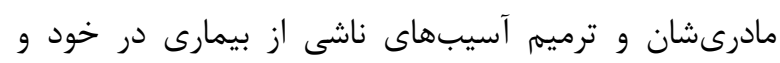

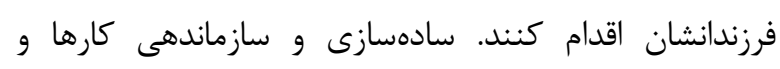

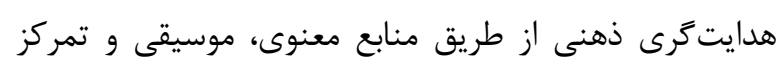

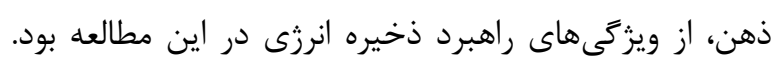

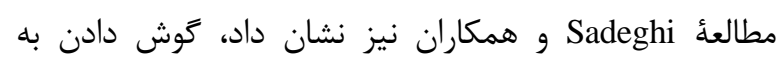

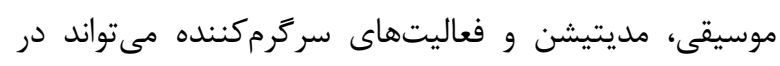

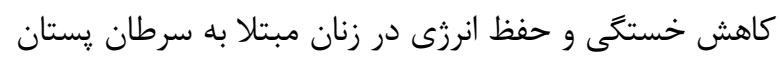

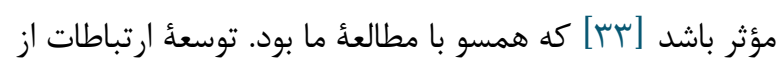

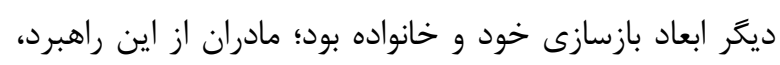

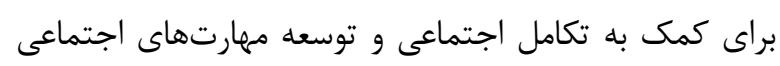

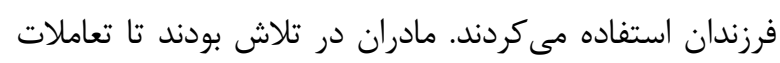

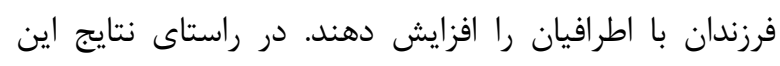

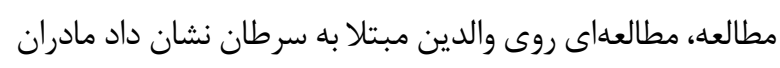
براى ايجاد وضعيت عادى در منزل حداكثر تلاش خول خود را به بـ كار

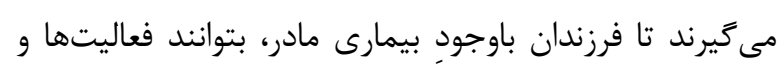

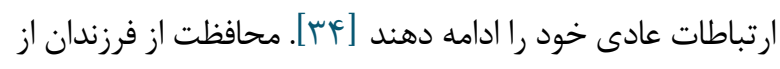

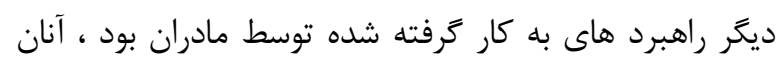

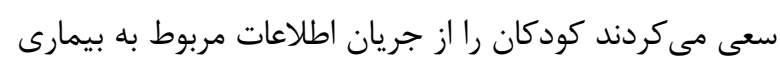

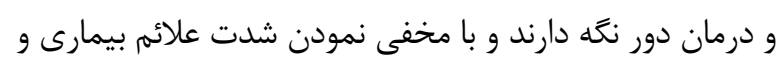

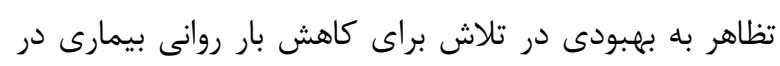

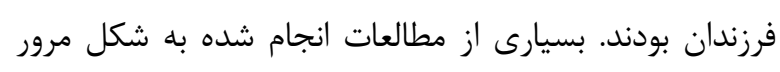

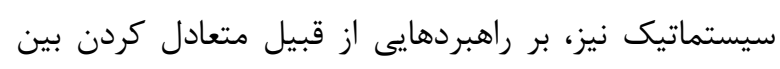

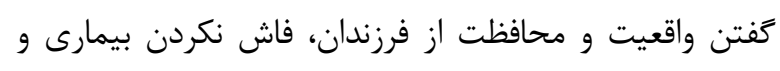

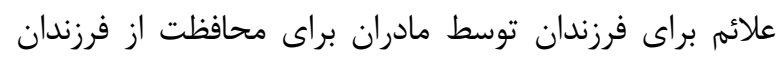

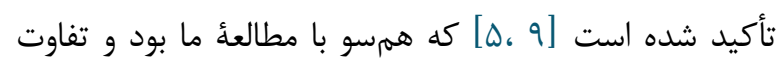

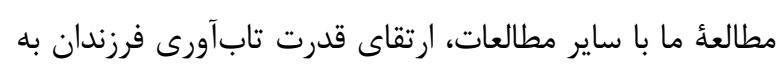

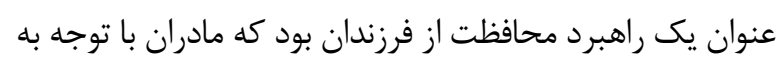

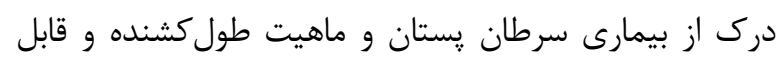

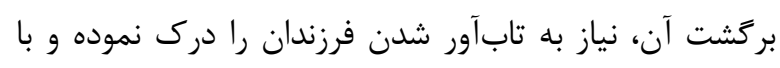

اطالاعاتى" بود. مادران مشاركت كننده، با به كاركيرى راهبرد آمادهازى خود، ضمن بازشناسى و اولويت بندى نياز هاى تون تغيير

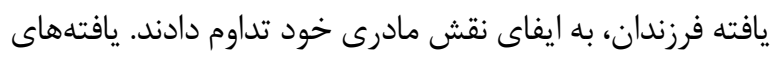

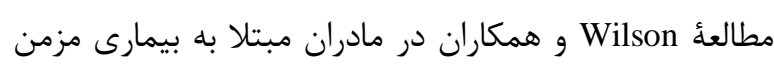

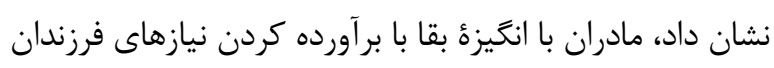

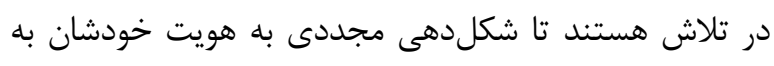

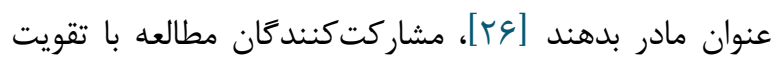
منابع خود انكيزشى از قبيل عشق فرزندى، ترغيب و تشويق

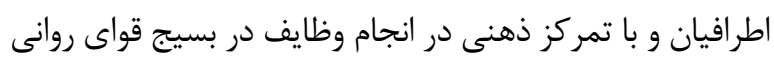

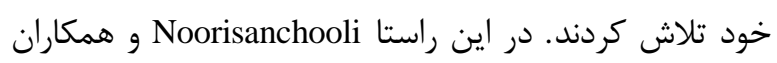

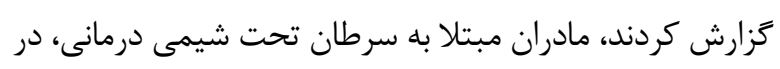

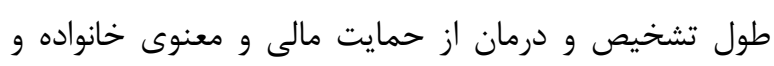

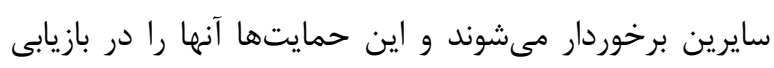

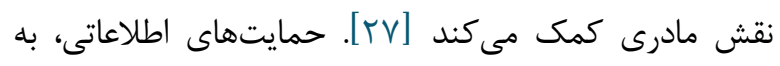

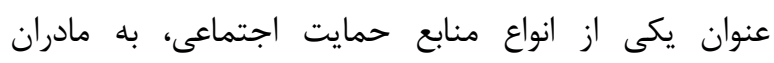

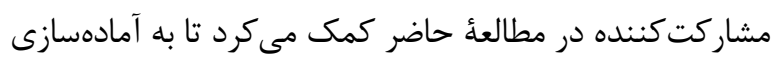

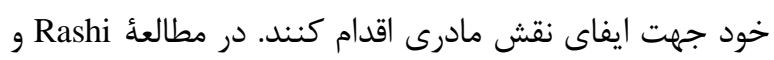

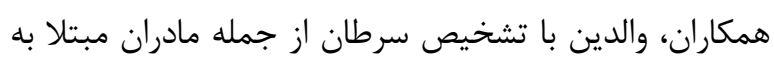

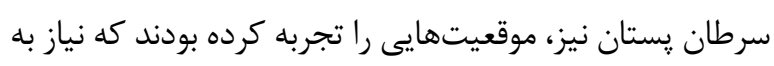

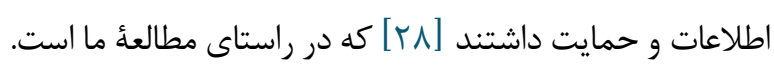
دومين طبقع ظاهرشده در صحبت با مشاركت كنندكان

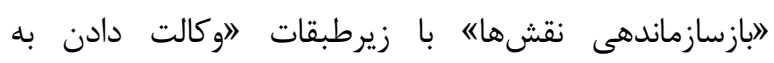

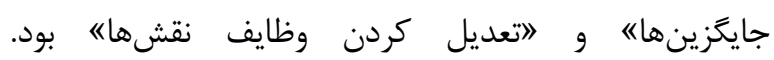

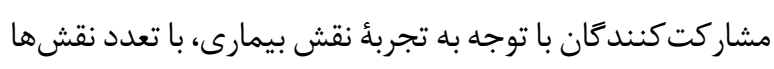

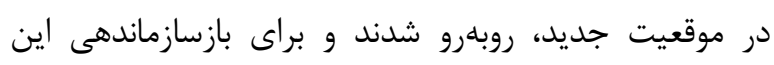

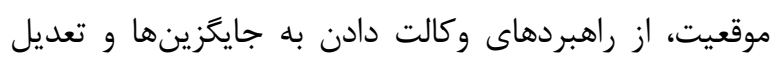

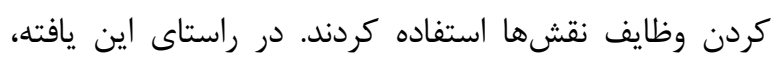

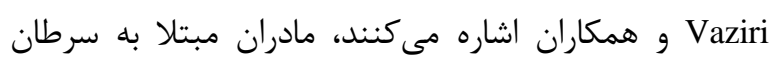

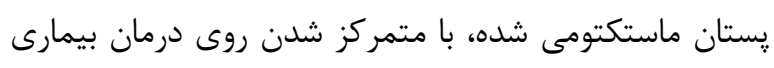

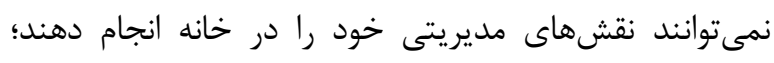

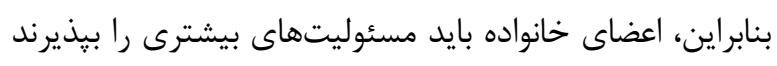

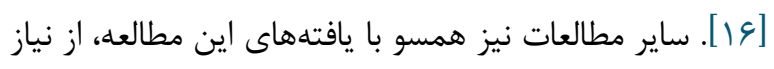

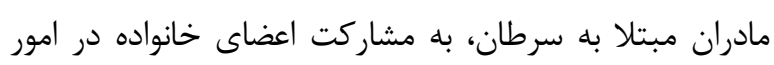

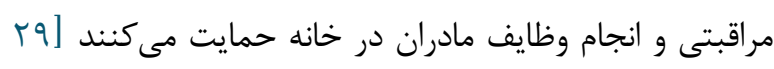

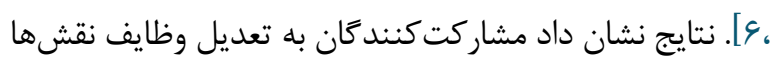

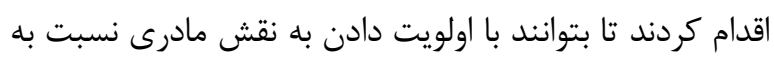

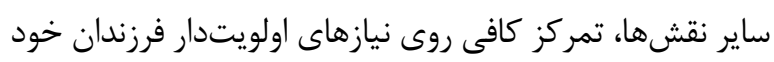

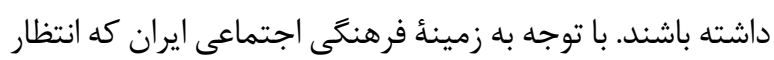

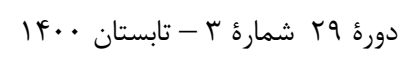




\section{نتيجه كيرى}

مادران با كسب حمايت از منابع درون و خارج خانواده، به

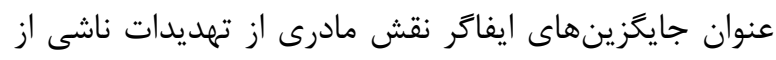

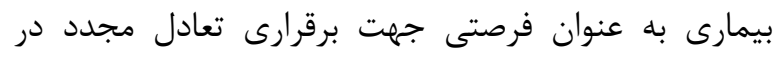

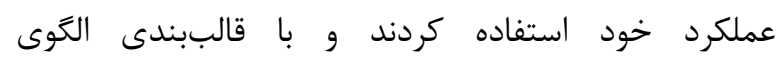

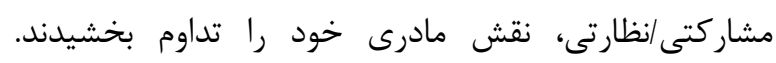

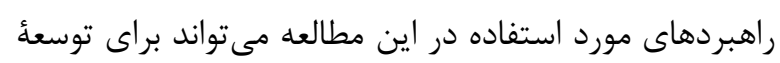

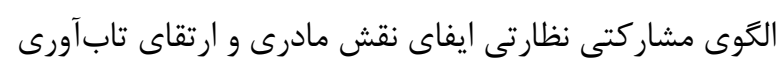

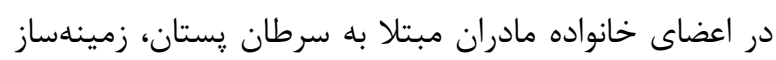

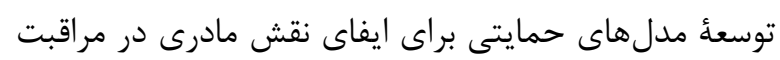

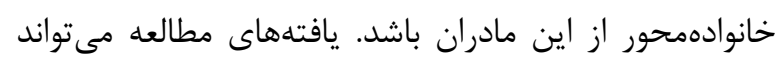

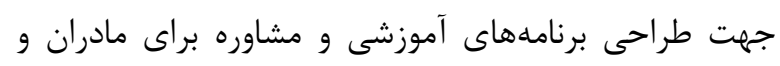

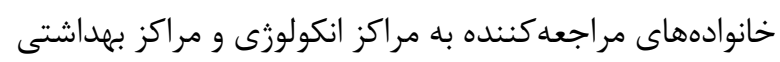
استفاده شود. متخصصان مراقبت سلامت مى توانند در ارائه

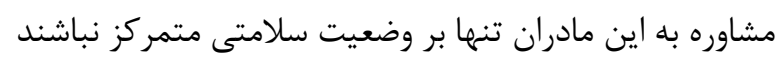

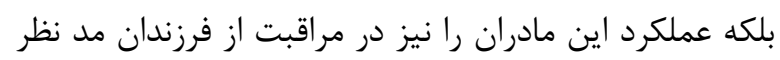

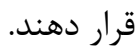

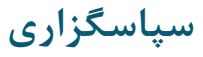

اين مقاله بركرفته از رساله دكتراى يرستارى است كه از سوى معاونت تحقيقات و فناورى و كميته اخلاق دانشكاه

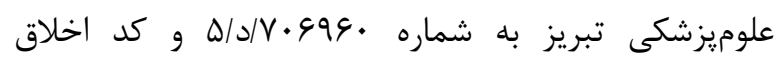

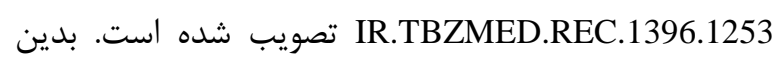

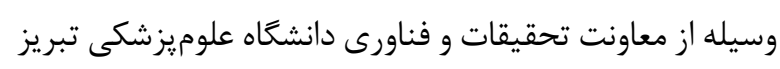

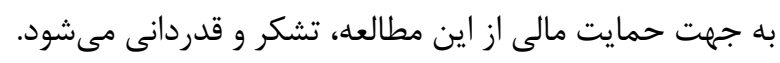
همجنين از تمامى مشاركت كنند

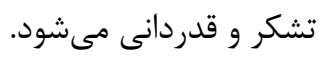

$$
\text { تعارض در منافع }
$$

نويسندكان هيج كونه تعارض منافعى ندارند.

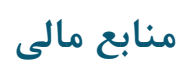

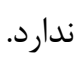

تفويض مسئوليتهاى بيشتر به فرزندان، به آن توجه خاصى

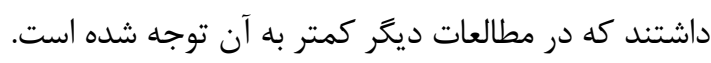

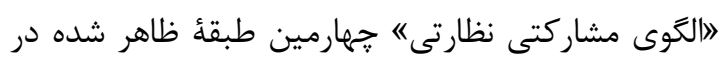

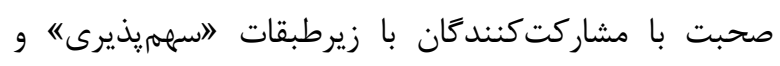

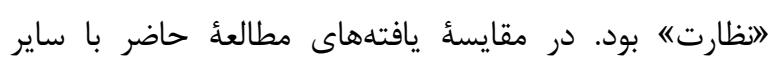

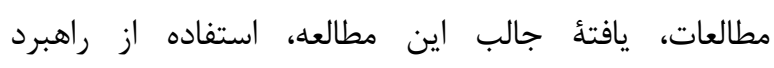

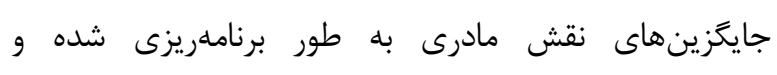

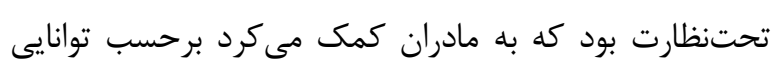

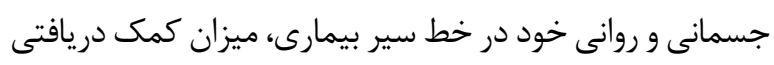

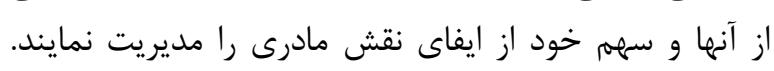

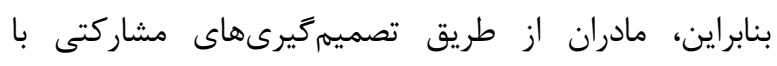

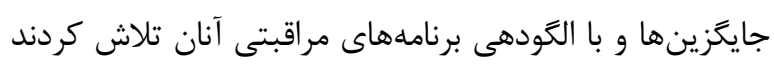

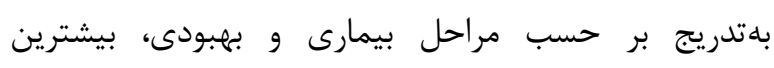

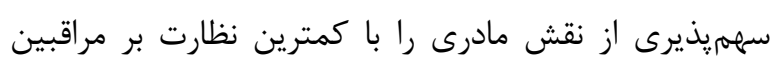
جايگزين كسب كنند. مطالعات متعددى نشان دادند كه مادران

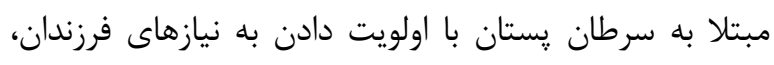

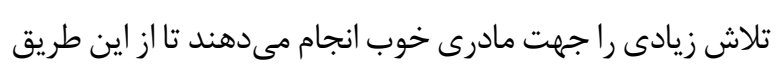

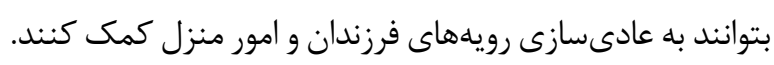

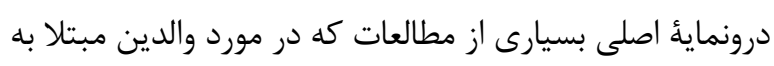
سرطان انجام شده، از قبيل تلاش برائ مارئ مادرى خوب، حفظ

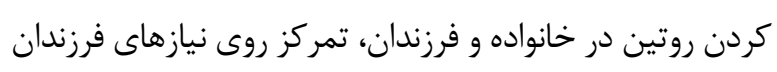

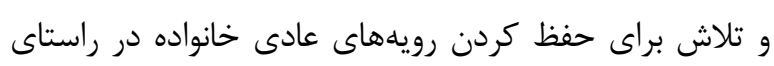

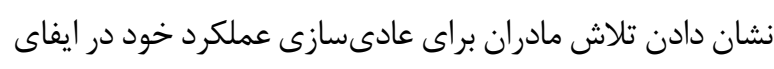

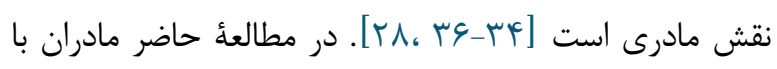

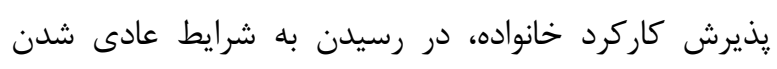

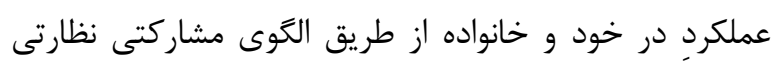

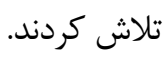
با وجود نكات قوت مطالعهُ حاضر از جمله بالابودن تعداد مصاحبهها، اين مطالعه نيز داراى محدوديت هايى است از إن جمله

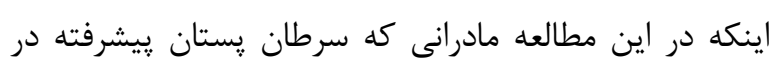

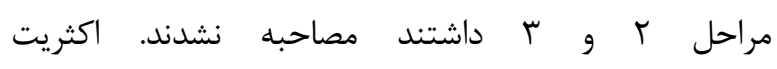
مشاركت كنندكان، متعلق به سطوح متوسط اجتماعى، فرهنغى آنى

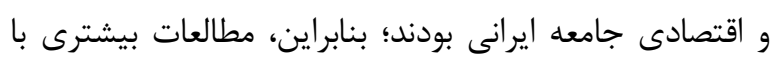

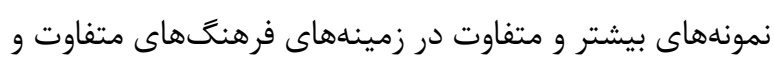
در مراحل پيشرفته بيمارى نياز هست. 


\section{References}

1. Haghighat S, Akbari M, Ghaffari S, Yavari P. Standardized breast cancer mortality rate compared to the general female population of Iran. Asian Pac J Cancer Prev. 2012; 13(11):5525-8. [DOI:10.7314/AP]CP.2012.13.11.5525] [PMID]

2. Shahidsales S, Hosseini S, Ahmadi-Simab S, Ghavam-Nasiri M. The importance of prognostic factors (ER, PR, P53) in breast cancer and their relationship with stage of disease. Med J Mashhad Univ Med Sci. 2014; 57(2):457-63.

3. Alligood M, Tomey A. Nursing theorists and their work. 5 ed. St. Louis: Elsevier; 2014.

4. Brown SG, Hudson DB, Campbell-Grossman C, Kupzyk KA, Yates BC, Hanna KM. Social support, parenting competence, and parenting satisfaction among adolescent, African American, mothers. West J Nurs Res. 2018; 40(4):502-19. [DOI: 10.1177/0193945916682724] [PMID] [PMCID]

5. Vallido T, Wilkes L, Carter B, Jackson D. Mothering disrupted by illness: a narrative synthesis of qualitative research. J Adv Nurs. 2010; 66(7):1435-45. [DOI:10.1111/j.13652648.2010.05350.x] [PMID]

6. Ambrósio DCM, Santos MAd. Social support to women after mastectomy: a review study. Cien Saude Colet. 2015; 20(3):851-64. [DOI: 10.1590/1413-81232015203.13482014] [PMID]

7. Bultmann JC, Beierlein V, Romer G, Möller B, Koch U, Bergelt C. Parental cancer: Health-related quality of life and current psychosocial support needs of cancer survivors and their children. Int J Cancer. 2014; 135(11):2668-77. [DOI: 10.1002/ijc.28905] [PMID]

8. Yfantis A, Intas G, Tolia M, Nikolaou M, Tsoukalas N, Lymperi M, et al. Health-related quality of life of young women with breast cancer. Review of the literature. J BUON. 2018; 23(1):16.

9. Tavares R, Brandão T, Matos PM. Mothers with breast cancer: A mixed-method systematic review on the impact on the parent-child relationship. Psycho-Oncology. 2018; 27(2):367-75. [DOI:10.1002/pon.4451] [PMID]

10. Strickland JT. Helene Hudson Lecture Young mothers' engagement with the cancer care system. Can Oncol Nurs J/Revue canadienne de soins infirmiers en oncologie. 2015;25(3):270-4.

11. Mousvi Diva R, Moghadam N, Amani O. Evaluating family functioning and spiritual health in women with breast cancer, cancer-treated and healthy women. Iran J Psych Nurs. 2017; 5(5):4956. [DOI: 10.21859/ijpn-05057]

12. Goodwin S, Huppatz K. Mothers making class distinctions: the aesthetics of maternity. The Good Mother: Contemporary Motherhoods in Australia. Sydney: Sydney University Press; 2010. p. 69. [DOI:10.2307/j.ctv1sr6kgj.8]

13. Bultmann JC BV, Romer G, Möller B, Koch U, Bergelt C. Parental cancer: Health-related quality of life and current psychosocial support needs of cancer survivors and their children. Int $\mathrm{J}$ Cancer 2014; 135(11):77-2668. [DOI: 10.1002/ijc.28905] [PMID]

14. Whitehead L, Jacob E, Towell A, Abu-Qamar Me, Cole-Heath A. The role of the family in supporting the self-management of chronic conditions: A qualitative systematic review. J Clinic Nurs. 2018; 27(1-2):22-30. [DOI:10.1111/jocn.13775] [PMID]

15. Drageset S, Lindstrøm TC, Giske T, Underlid K. Women's experiences of social support during the first year following primary breast cancer surgery. Scand J Caring Sci. 2016; 30(2):340-8. [DOI: 10.1111/sCS.12250] [PMID]

16. Vaziri S, Lotfi Kashani F, Akbari ME, Ghorbani Ashin Y. Comparing the motherhood and spouse role in women with breast cancer and healthy women. Iranian J Breast Dis. 2014; 7(2):76-83.

17. Ruddick S. Maternal thinking. Fem Stud. 1980; 6(2):342-67. [DOI: 10.2307/3177749]

18. De Castro EK, Dornel ALK, De Sousa MA. The experience of motherhood during treatment. Int $\mathbf{J}$ Behav Med. 2018; 23(39559):1-16. [DOI: 10.4025/psicolestud.v23i0.39559]

19. Hashemi-Ghasemabadi M, Taleghani F, Kohan S, Yousefy A. Living under a cloud of threat: the experience of Iranian female caregivers with a first-degree relative with breast cancer. PsychoOncology. 2017; 26(5):625-31 [DOI: 10.1002/pon.4198] [PMID]

20. Arber A. How do nurses "Think Family" and support parents diagnosed with cancer who have dependent children? Asia-Pac J Oncol Nurs. 2016; 3(3):214. [DOI:10.4103/2347-5625.189809] [PMID] [PMCID]

21. Polit DF, Beck CT. Essentials of nursing research: Appraising evidence for nursing practice. 7 ed. Philadelphia: Lippincott Williams \& Wilkins; 2010.

22. Graneheim UH, Lundman B. Qualitative content analysis in nursing research: concepts, procedures and measures to achieve trustworthiness. Nurs Educ Today. 2004; 24(2):105-12. [DOI: 10.1016/j.nedt.2003.10.001] [PMID]

23. Software V. MAXQDA analytics pro [Computer program]. Author Berlin; 2016.

24. Lincoln YS, Guba EG. Naturalistic Inquiry. illustrated, reprint ed. New York: Sage publications; 1985.

25. Ainsworth MDS, Blehar MC, Waters E, Wall SN. Patterns of Attachment: A psychological study of the strange situation. Classic ed. London: Taylor \& Francis; 2015. [DOI: 10.4324/9781315802428]

26. Wilson S. 'When you have children, you're obliged to live' 1: motherhood, chronic illness and biographical disruption. Sociol Health Illn. 2007;29(4):610-26. [DOI:10.1111/i.14679566.2007.01008.x] [PMID]

27. Noorisanchooli H, Rahnam M, Haghighi MJ, Hashemi SA, Younesbarani Z. The familial experiences of women with breast cancer referring to chemotherapy clinic: A qualitative study. Clin

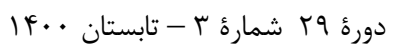

$$
\text { مجله مراقبت يرستارى و مامايى ابنسينا }
$$


Cancer Invest J. 2018; 7(6):210-6 [DOI: 10.4103/ccij.ccij 92 18]

28. Rashi C, Wittman T, Tsimicalis A, Loiselle CG. Balancing illness and parental demands: Coping with cancer while raising minor children. Oncol Nurs Fourm. 2015; 42(4):337-44. [DOI: 10.1188/15.ONF.337-344] [PMID]

29. Bekteshi V, Kayser K. When a mother has cancer: pathways to relational growth for mothers and daughters coping with cancer. Psycho-Oncology. 2013; 22(10):2379-85 [DOI: 10.1002/pon.3299] [PMID]

30. Kian F, Etemadi O, Bahrami F. Exploring parenting styles of insecure Iranian mothers. Early Child Dev Care. 2019:1-8.

31. Kuswanto CN, Stafford L, Sharp J, Schofield P. Psychological distress, role, and identity changes in mothers following a diagnosis of cancer: A systematic review. Psycho-Oncology. 2018; 27(12):2700-8. [DOI:10.1002/pon.4904] [PMID]

32. Mazzotti E, Serranò F, Sebastiani C, Marchetti P. Mother-child relationship as perceived by breast cancer women. Psychology. 2012;3(12):1027. [DOI: 10.4236/psych.2012.312154]

33. Sadeghi E, Gozali N, Tabrizi FM. Effects of energy conservation strategies on cancer related fatigue and health promotion lifestyle in breast cancer survivors: A randomized control trial. Asian Pac J Cancer Prev. 2016; 17(10):4783-90.

34. Helseth S, Ulfsæt N. Parenting experiences during cancer. J Adv Nurs. 2005; 52(1):38-46. [DOI:10.1111/j.1365-2648.2005.03562.x] [PMID]

35. Öhlén J, Holm AK. Transforming desolation into consolation: Being a mother with life-threatening breast cancer. Health Care Women Int. 2006; 27(1):18-44.

[DOI: 10.1080/07399330500377226] [PMID]

36. Semple C, McCaughan E. Family life when a parent is diagnosed with cancer: Impact of a psychosocial intervention for young children. Eur J Cancer Care. 2013; 22(2):219-31. [DOI:10.1111/ecc.12018] [PMID] 